THE PELAGIC COPEPODS OF THE IZU REGION, MIDDLE JAPAN SYSTEMATIC ACCOUNT XIII PARAPONTELLIDAE, ACARTIIDAE AND TORTANIDAE-

$\operatorname{AUTHOR}(\mathrm{S})$ :

Tanaka, Otohiko

CITATION:

Tanaka, Otohiko. THE PELAGIC COPEPODS OF THE IZU REGION, MIDDLE JAPAN SYSTEMATIC ACCOUNT XIII -PARAPONTELLIDAE, ACARTIIDAE AND TORTANIDAE-.

PUBLICATIONS OF THE SETO MARINE BIOLOGICAL LABORATORY 1965, 12(5): 379-408

ISSUE DATE:

1965-03-10

URL:

http://hdl.handle.net/2433/175378

RIGHT: 


\title{
THE PELAGIC COPEPODS OF THE IZU REGION, MIDDLE JAPAN SYSTEMATIC ACCOUNT XIII

\author{
PARAPONTELLIDAE, ACARTIIDAE AND TORTANIDAE
}

\author{
OTOHIKo TANAKA
}

Fisheries Department, Faculty of Agriculture, Kyushu University

With 11 Text-figures

\section{Family PARAPONTELLIDAE \\ Genus Bathypontia SARs.}

The genus was created by SARS in 1905 to accomodate a species, Bathypontia elongata taken from the Atlantic. He added the second species, B. minor from the Atlantic. A. Scotr recorded the third species, B. spinifera in the collections of the "Siboga". In 1920 Sars described the another species B. elegans. Sewell has failed to recognise either of them from the Indian seas. I found two species in my collections from the Izu region, which appear to be undescribed, to which I propose the names similis and longicornis. The genus is characterized by having the exopod longer than the endopod in the 2nd antenna. Isocalanus described by WOLFENDEN in the "Südpolar Expedition" is clearly congeneric with Bathypontia SARS.

\section{Bathypontia similis sp. nov.}

(Fig. 241, a-k)

Female. Length, $2.81 \mathrm{~mm}$ : cephalothorax, $2.06 \mathrm{~mm}$; abdomen, $0.75 \mathrm{~mm}$. The cephalothorax oblong ovate in outline. The head separates from the 1 st thoracic segment, so are the 4 th from the 5 th. The last thoracic segment asymmetrical; the lateral corner of the last thoracic segment triangular with a blunt process on each side but produced more on the left side. The rostrum one-pointed, unevenly produced at the apex.

The abdomen 4-jointed, contains 2.75 times in the length of the cephalothorax; the segments and furca are in the proportional lengths as 42:19:16: $14: 9=100$. The genital segment has a small swelling on each of the lateral

Publ. Seto Mar. Biol. Lab., XII (5), 1965. (Article 29) 
margins near the base; the 2nd and 3rd segments are fringed with fine teeth on the distal margin. The furcal rami as long as wide, with 4 apical setae of which the 2nd is the longest.

The 1st antenna 23-jointed, reaches back to the posterior margin of the last thoracic segment; the segments $8-9$ and $24-25$ are fused respectively. The

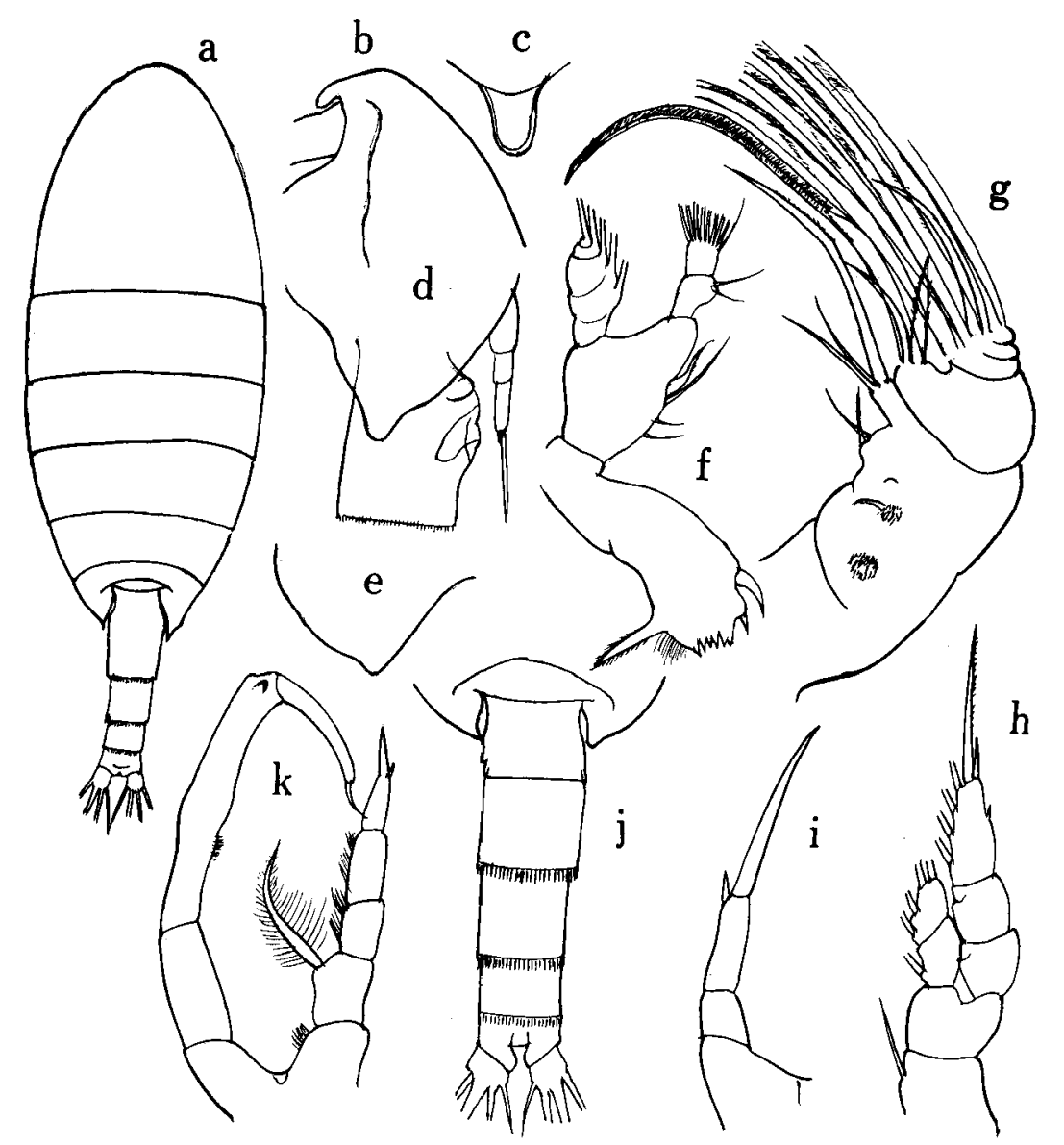

Fig. 241. Bathypontia similis sp. nov.

Female: a, dorsal aspect; b, head, lateral aspect; c, rostrum ; d, last thoracic segment and genital segment, lateral aspect, right side; e, last thoracic segment, lateral aspect left side; f, mandible; $g$, 2nd maxilla; h, 1st leg; $i$, 5th leg. Male : $j$, last thoracic segment and abdomen, dorsal aspect; $k, 5$ th pair of legs.

2nd antenna has the exopod and endopod of about equal lengths; the exopod 7 -jointed; the 1st basal segment has fine hairs on the posterior surface. The mandible as that of Bathypontia spinifera A. Scots; the biting part with 2 large spiniform teeth on the upper margin, the inner marginal seta of the blade 
strong; the exopod 5-jointed, with a small terminal segment which is devoid of setae. The 1st maxilla has the following numbers of setae on the various appendages : 4 setae on the outer lobe, 10 setae on the exopod, 1 seta on the endopod, 1 seta on the 3rd inner lobe, 1 seta on the 2nd inner lobe, 8 setae on the 1st inner lobe. The 2nd maxilla strong with peculiar setae on the distal segments. The maxilliped feeble.

The 1st leg has 3 -jointed exopod and 2-jointed endopod; the 1st and 2 nd segments of the exopod have no outer edge spines, the 3rd segment has an outer marginal spine. The 2 nd leg has 3 -jointed exopod and endopod; the terminal spine of the exopod has 39 teeth; the 2 nd basal segment has a strong and slightly curved spine reaching the base of the outer edge spine of the 1st segment of the exopod. The 4 th leg has 3-jointed exopod and endopod; the 1st basal segment has no inner marginal setae. The 5th pair of legs 3 -jointed; the apical spine of the 3rd segment of the exopod about as long as the combined lengths of 3 segments of the exopod taken together; the outer marginal spine small.

Male. Length, $2.66 \mathrm{~mm}$ : cephalothorax, $1.95 \mathrm{~mm}$; abdomen, $0.71 \mathrm{~mm}$. The general appearance as in the female; the last thoracic segment symmetrical, produced posteriorly into a triangular process on each side.

The abdomen 5-jointed; the segments and furca are in the proportional lengths as $21: 24: 21: 16: 8: 10=100$; the 2 nd to 4 th segments are fringed with fine teeth on the distal margin; the anal segment produced on the inner distal margin.

The right 1st antenna is modified into a grasping organ; the segments 17-18 without remarkable processes. The mouth parts as in the female. The right 2nd swimming leg has a strong outer edge spine on the 2 nd segment of the exopod; the distal outer edge spine of the 3rd segment of the exopod strong.

The 5th pair of legs quite resembles that of B. spinifera A. SсOтT; the right leg has 2-jointed exopod; the endopod absent; the left leg with 3-jointed exopod, the segments are of about equal lengths; the 2nd basal segment carries a long seta on the inner distal corner.

Remarks. The specimen closely resembles B. spinifera A. Scott or B. elongata SARS except that in the present specimen the posterior margin of the last thoracic segment is asymmetrical in the female, and that the right 2nd leg of the male differs from those of the formers in the asymmetry of the outer edge spine of the 2 nd and $3 r d$ segments of the exopod. The specimen differs also from B. minor SARS in the shape of the 1st thoracic segment of the female.

Occurrence. 3 females and a male from Sagami Bay, and 1 female and a male from Suruga Bay in 1937 from deep layer.

Distribution. The Pacific coast of Middle Japan. (the present record). 
Bathypontia longicornis sp. nov.

(Fig. 242, a-b)

Male. Length, $5.18 \mathrm{~mm}$ : cephalothorax, $3.87 \mathrm{~mm}$; abdomen, $1.31 \mathrm{~mm}$. The general appearance as in the foregoing species. The head separates from the 1st thoracic segment; the anterior margin of the head is pointed when viewed

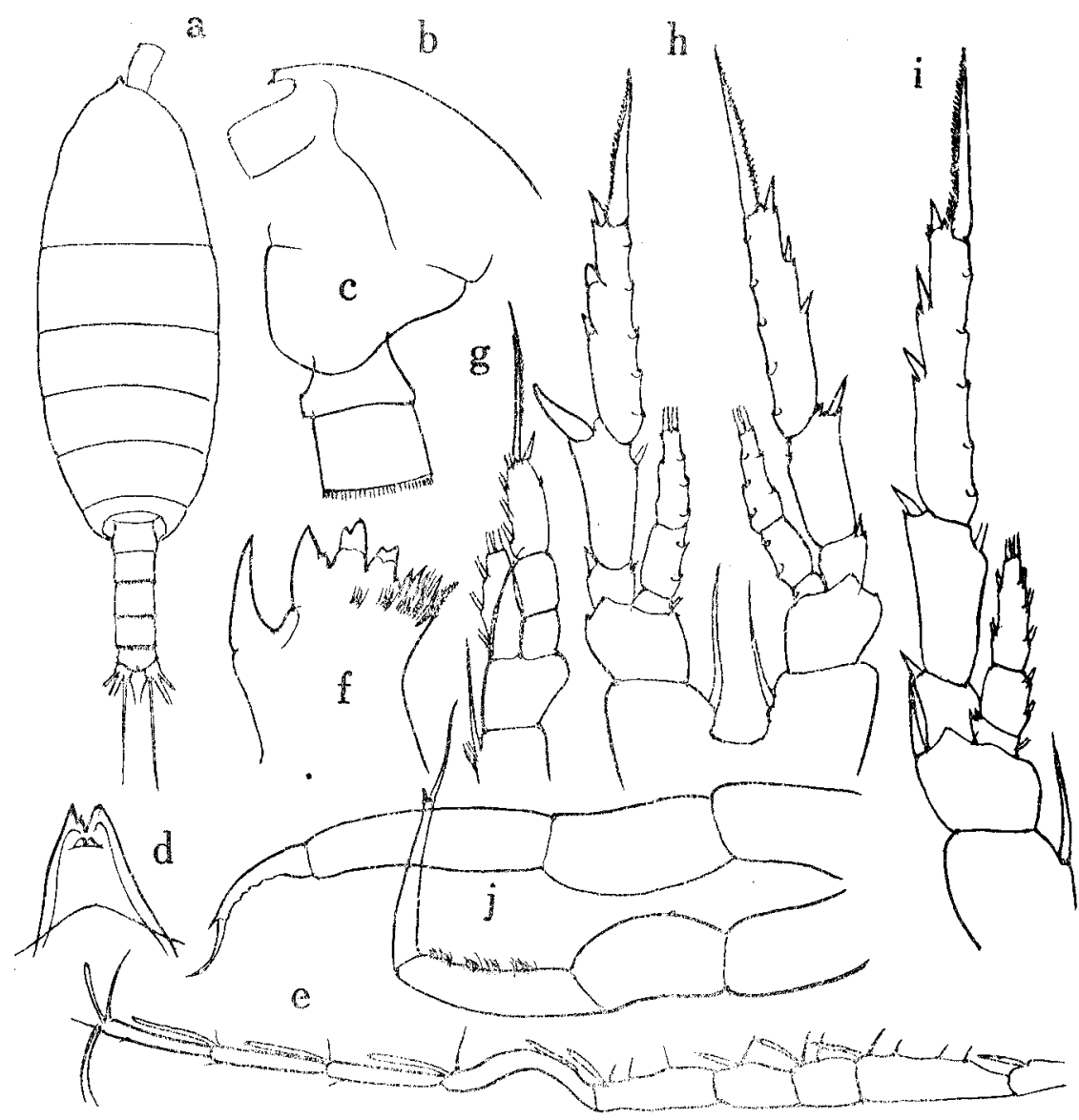

Fig. 242. Bathypontia longicornis sp. nov.

Male: a, dorsal aspect; b, head, lateral aspect; c, last thoracic segment, lateral aspect; d, rostrum ; e, clasping antenna ; f, mandible blade; g, 1st leg; h, 2nd pair of legs; $i$, 3rd leg; $j$, 5th pair of legs.

in dorsal aspect. The last 2 thoracic segments are separate; the lateral corner of the last thoracic segment narrowly rounded. The rostrum pointed and bifurcate at the apex, and has a small denticle at the base of the left ramus; in anterior and lateral aspects a ponted process is observed on the distal portion of the basal part. 
The abdomen 5-jointed, the segments and furca are in the proportional lengths as $18: 20: 20: 18: 18: 6=100$; the genital segment is slightly swollen on the ventral distal margin. The furcal rami $2 / 3$ as long as wide.

The left 1st antenna extends to the distal margin of the 3rd abdominal segment; the segments are in the following proportional lengths:

$\begin{array}{rrrrrrrrrrrrrrrrr}\text { Segment } & 1 & 2 & 2 & 3 & 4 & 5 & 6 & 7 & 8-9 & 10 & 11 & 12 & 13 & 14 & 16 & 17 \\ 42 & 35 & 18 & 18 & 18 & 18 & 18 & 18 & 39 & 25 & 25 & 28 & 50 & 50 & 46 & 46 \\ & & & & & & & & & & & & & & & \\ 18 & 19 & 20 & 21 & 22 & 23 & 24-25 \\ 50 & 60 & 63 & 67 & 82 & 82 & 78=1000 & & & & & & & \end{array}$

The right antenna 19-jointed, forms a grasping organ and has a general resemblance to that of $B$. elongata SARs. The 2nd antenna has the exopod much shorter than the endopod $(28: 34)$. The mandible has the exopod about as long as the endopod (11:10); the biting part as that of B. elegans SArs. The 1st and 2nd maxillae and the maxilliped as those of B. elongata SARs.

The 1st leg has 3-jointed exopod and 1-jointed endopod; the 1st and 2nd segments of the exopod are devoid of outer edge spines. The 2nd leg has 3-jointed exopod and endopod; the outer edge spine of the 2nd segment of of the exopod of the right leg much stronger than that of the left leg; the middle outer margin of the 3 rd segment of the exopod not pointed at the apex; the terminal spine of the exopod has 48 teeth. The 3rd leg elongated; the outer edge spine of the 2 nd basal segment extends to the distal margin of the 1st segment of the exopod; the terminal spine of the exopod has 41 teeth; the 1st segment of the endopod carries 2 denticles on the outer distal corner. The 4 th leg has 28 teeth on the terminal spine of the exopod which is about $2 / 3$ the length of the 3rd segment of the exopod.

The 5 th pair of legs slightly asymmetrical; in the right leg the 2 nd segment of the exopod slightly serrated on the inner margin; the outer distal corner of the segment is furnished with a minute spine. In the left leg the 1st segment of the exopod is furnished with tufts of of stiff hairs on the inner margin; the 2nd segment has a minute spine on the outer distal corner.

Occurrence. One male from depths $1000-0$ in Sagami Bay and one male from depths $1800-1000 \mathrm{~m}$ in Suruga Bay, March 1940.

Distribution. The Pacific coast of Middle Japan (the present recod).

\section{Genus Temorites SARS.}

The genus is created by SARS in 1900 and accomodates T. brevipes SARS taken from the North Pacific Ocean. The genus is closely allied to Bathypontia SARs, differing from the latter in having the exopod much longer than the endopod in the 2nd antenna. Brodsky recorded the occurrence of $T$. brevipes 
from the far-eastern and polar seas of the USSR. The species was found in my collections from the deep water of Sagami Bay.

\section{Temorites brevipes SARS.}

(Fig. 243, a-k)

Temorites brevipes, WILson, 1950, p. 343, pl. 35, fig. 539; BRODSKY, 1950, p. 417, text-fig. 295.

Female. Length, $1.71 \mathrm{~mm}$ : cephalothorax, $1.32 \mathrm{~mm}$; abdomen, $0.39 \mathrm{~mm}$. The cephalothorax ovate and robust in dorsal view. The head separates from the

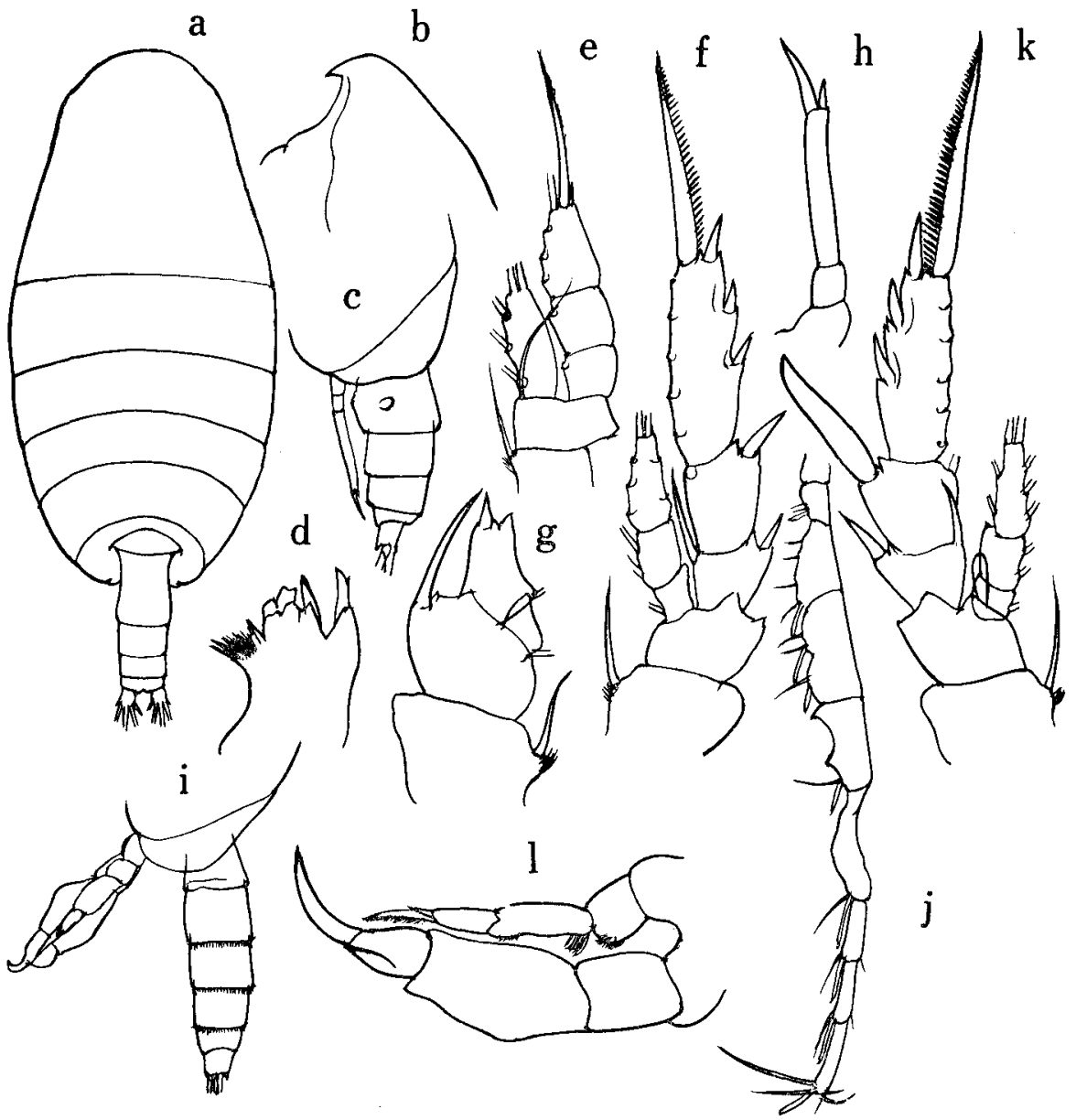

Fig. 243. Temorites brevipes SARS.

Female: $a$, dorsal aspect; $b$, head, lateral aspect; $c$, last thoracic segment and abdomen, lateral aspect; d, mandible blade; e, 1st leg; f, 2nd leg; g, basal joints of 3rd leg; h, 5th leg. Male: $i$, last thoracic segment and abdomen, lateral aspect; $j$, clasping antenna ; $\mathbf{k}$, right 2 nd leg; 1, 5th pair of legs. 
1st thoracic segment; so are the 4th from the 5 th; the segment rounded and slightly produced on the antero-ventral corner at the junction with the 4th segment. The rostrum bifurcate at the apex, ends in sharp points.

The abdomen 4-jointed, the segments and furca are in the proportional lengths as $40: 22: 18: 11: 9=100$. The genital segment 1.6 times as long as wide, not produced below. The furcal rami slightly wider than long, with 4 terminal setae and a small spine on the outer distal margin of the rami.

The 1st antenna 23-jointed, reaches back to the end of the genital segment; the segments are in the following proportional lengths:

$\begin{array}{rrrrrrrrrrrrrrrrr}\text { Segment } & 1 & 2 & 3 & 4 & 5 & 6 & 7 & 8-9 & 10 & 11 & 12 & 13 & 14 & 15 & 16 & 17 \\ 57 & 40 & 17 & 23 & 23 & 23 & 23 & 46 & 30 & 30 & 33 & 46 & 46 & 49 & 49 & 46 \\ & & & & & & & & & & & & & & \\ 18 & 19 & 20 & 21 & 22 & 23 & 24-25 & & & & & & & & \\ 46 & 55 & 57 & 57 & 57 & 61 & 86 & =1000 & & & & & & & \end{array}$

The 2nd antenna has the exopod as long as the endopod. The mandible has the exopod as long as the endopod; the biting part as shown in the figure. The 1st and 2nd maxillae as those of Bathypontia. The maxilliped as that of the genus Bathypontia, and has the segments in the proportionall lengths as $18: 20: 18$ (endopod).

The 1st leg has 3-jointed exopod and one-jointed endopod; the outer edge spine on the 1st and 2nd segments of the exopod and the outer mariginal spine of the 3 rd segment of the exopod absent; the 2nd basal segment is produced outwardly and carries a minute spines on the outer margin near the apex of the swelling. The 2nd leg has 3 -jointed exopod and endopod; the 1st segment of the exopod has a strong inner marginal spine reaching the distal end of the 2nd segment of the exopod; the terminal spine of the the exopod has about 45 teeth; the basal segment produced outwardly on the distal corner. The 3rd leg has a long and curved spine on the distal outer corner of the 2nd basal segment; the exopod missing in the present specimen. The 4 th leg without any distinct characters.

The 5th pair of legs symmetrical, with 2 apical spines, of which the inner one about 2 times as long as the outer one.

Male. Length, $1.88 \mathrm{~mm}$ : cephalothorax, $1.43 \mathrm{~mm}$; abdomen, $0.45 \mathrm{~mm}$. The general appearance as in the female. The abdomen 5 -jointed; the segments and furca are in the proportional lengths as $20: 20: 2016: 14: 10=100$. The genital opening on the left side; the 2nd to 4 th segments finely striated on the distal margin. The furcal rami as long as wide.

The grasping antenna on the right side; the segments 17-18 with 2 large teeth. The left antenna extends about to the end of the genital segment. The mouth parts and the 1st, 3rd and 4th legs as in the female.

The right 2 nd leg has a large outer edge spine on the 2nd segment of the 
exopod. The 5th legs has no endopod. The right leg with 2 -jointed exopod; the 1st joint of the exopod very conspicuous, the outer distal margin produced into a blunt triangular process; the 2nd segment ends in a strong curved spine, the distal outer margin of the segment carries a large spine. The left leg much smaller than the right leg, the exopod 2-jointed; the 1st segment is furnished with a tuft of hairs on the inner proximal margin; the 2nd segment ends in a strong spine furnished with scattered hairs on the inner margin; the segment has a small outer edge spine.

Remarks. The present specimens both female and male are much larger in size than those reported by SARS from the Norwegian North Polar Expedition. The specimen recorded by BRODSKY from the far-eastern and polar seas of the USSR agrees fairly with the Izu specimen in size.

Occurrence. Three females and two males from depths $1000-0 \mathrm{~m}$ in Sagami Bay.

Distribution. The species has been recorded from the Arctic.

\section{Genus Neopontella A. ScotT.}

The genus was created by A. Scotr to accomodate a species, Neopontella typica, A. ScotT taken in the collections of the "Siboga". No examples have been recorded from the Indian seas by SEwELL. I have not found any species of the genus from the Izu region.

\section{Family ACARTIIDAE}

\section{Genus Paralabidocera (I. C. Thompson).}

The genus was created by I. C. Thompson to accomate Paralabidocera antarctica. The species is the Antarctic form and has not been met with in the Izu region.

\section{Genus Acartia DANA.}

A. Scott recorded the occurrence of Acatia danae Giesbrecht, A. erythraea Giesbrecht, A. negligens DadA, A. spinicauda Giesbrecht in the collections of the "Sigoga". SEwEll recorded the occurrence of a vast number of species from the Indian seas, and arranged them under the sub-genera proposed by Steuer, namely, Acartia (Acartiella) tortaniformis Sewell, A. (Acartiella) gravelyi Seweld, A. (Acartiella) kempi Sewell, A. (Acartiella) major Sewell, A. (Acartiella) minor Sewell, A. (Euacartia) southwelli $\mathrm{S}$ eweld, A. (Acanthacartia) chilkaensis, $A$. (Acanthacartis) amboinensis CARL, A. (Odontacartia) bispinosa CARL, A. (Odontacartia) centrura Giesbrecht, A. (Odontacartia) erythrea Giesbrecht, A. (Odontacartia) 
pacifica Steuer, A. (Odontacartia) spinicauda Giesbrecht, A. (Planktacartia) danae Giesbrecht and $A$. (Planktacartia) negligens DANA. The majority of the species, are as SEWELL pointed out, brackish water forms, the pelagic forms belong to the subgenus Odontacartia and Planktacartia. In Japanese waters the following species have been recorded by several authors: A. bifilosa (Giesbrecht), A. longiremis LILLJEBORG and $A$. danae were recorded by SATo from the northern water of near Hokkaido; MoRI (1937) recorded A. clausi, A. longiremis and A. hamata MoRI from the neighbouring waters of Japan. He described A. japonica MORI and A. sinjiensis MORI from the Sea of Japan; he further recorded the occurrence of $A$. erythraea, A. spinicauda and A. tokiokai Morr and A. hamata MorI from Iwayama Bay, Palao. MorI's sinjiensis is identical with A. plumosa Scotr. A. japonica Morr appears to be identical with $A$. amboinensis in the armature of the 1st antenna and in the shape of the female 5th pair of legs. I obtained A. clausi, A. amboinensis, A. pacifica, A. danae, A. negligens and $A$. steueri Smirnov in my collections. A. erythraea was unfortunately absent but appears to be fairly commom in the adjacent waters of Japan. The species of the genus Acartia are very characteristic in its geographical distribution. The material from the Izu region is insufficient to clear out the geographical distribution of the species in Japanese waters, and further studies are needed.

Acartia is divided into two groups: 1). Rostral filament absent, including the subgenera Acartiura Steuer and Acartiella Sewell; 2). Rostral filament present, including Euacartia Steuer, Acanthacartia Steuer, Odontacartia Steuer and Planktacartia Steuer. The present specimens belong to a greater part to the rostrated group.

\section{Acartia (Acartiura) clausi GIESBRECHT.}

(Fig. 244, a-e)

Acartia clausi, GIESBRECHT, 1892, p. 507, t. 30, figs. 2, 4, 13-15, 17, 28, 36, 37 ; t. 42, fig. 32 ; t. 43, figs. 3, 5, 14 ; SARS, 1903, p. 150, pl. ci ; 1925, p. 361 ; STEUER, 1923, p. 5 ; WiLSON, 1932 , p. 146 ; JESPERSEN, 1934, p. 123 ; MORr, 1937, p. 103, pl. 50, figs. 8-13; WiLSON, 1950, p. 151 ; BRODSKY, 1950, p. 420, text-fig. 296.

Female. Length, $1.06-1.22 \mathrm{~mm}$. The rostral filaments absent. The last thoracic segment is devoid of spines on the lateral distal margin. The abdomen 3-jointed, and is contained 3.3 times in the length of the cephalothorax; the proportional lengths of the segments and furca are as $41: 24: 14: 21=100$. The genital and 2nd segments are fringed with fine teeth on the distal margin. The thorax segments and the genital segment are covered with fine hairs.

In the 5th pair of legs the middle segment squarish in shape; the claw-like spine swollen at the basal portion and spinulose on each side; the outer marginal seta longer than the claw. 
Male. Length, $0.94-1.19 \mathrm{~mm}$. The abdomen is contained 3.1 times in the length of the cephalothorax. The lateral corner of the last thoracic segment is furnished with short hairs. The abdominal segments and furca are in the proportional lengths as $15: 30: 19: 7: 11: 18=100$; the 2 nd to 4 th segments are fringed with minute spinules on the dorsal distal margin. The 5 th pair of legs agrees well with the figures given by previous authors.

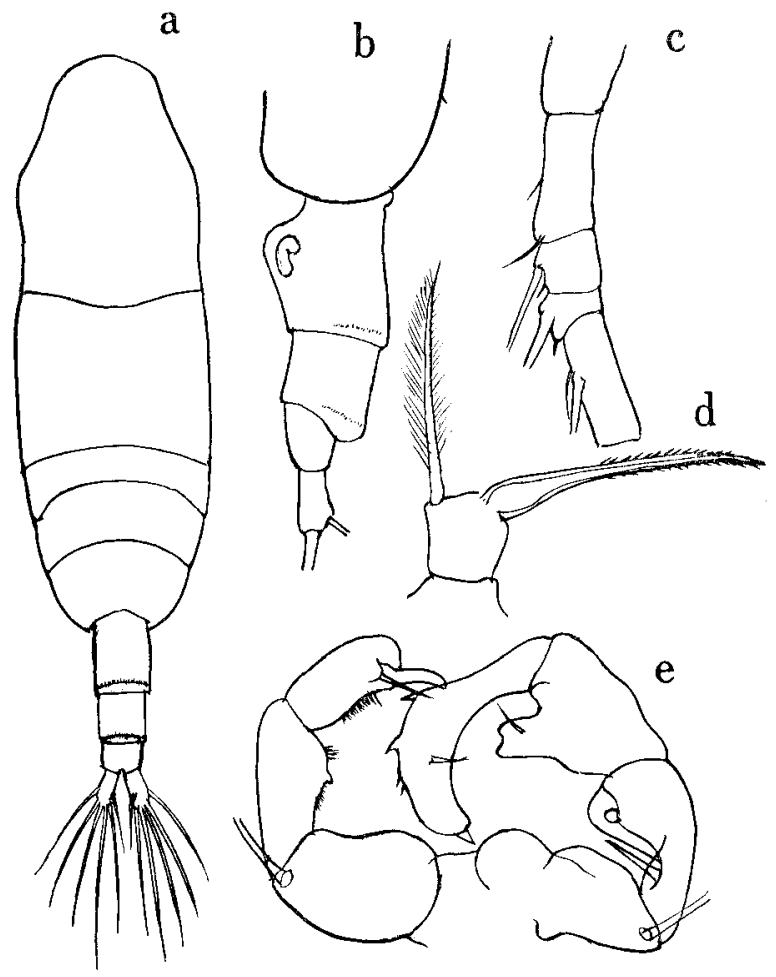

Fig. 244. Acartia clausi Giesbrecht.

Female: $a$, dorsal aspect; $b$, last thoracic segment and abdomen, lateral aspect; $c$, proximal portion of 1st antenna; d, 5th leg. Male: e, 5th pair of legs.

Occurrence. The species is very common in the Izu region all the year round

Distribution. It is widely distributed in the temperate waters of the Pacific, Atlantic. The species has not been recorded from the tropical region of the Indo-Pacific.

Acartia (Acanthacartia) steueri SmiRnov.

(Fig. 245, a-g)

Acartia steueri, SMIRNov, 1936, p. 87. 90, figs. 1-3; BrodSKY, 1950, p. 425, text-fig. 300 . 
Female. Length, $1.38-1.60 \mathrm{~m}$. The rostral filaments long and slender. The abdomen is contained 3 times in the length of the cephalothrax. The last thoracic segment has rows of spinules on the distal margin. The abdominal segments and furca are in the proportional length measured in $0.01 \mathrm{~mm}$ $16: 7: 6: 9$; the genital and the 2nd segments are fringed with fine teeth on the dorsal distal margin.

The 1st antenna extends to the middle of the genital segment; the 1st segment has no spine on the anterior margin. The 5th pair of legs has narrow basal segments; the terminal spine long and curved on the middle section

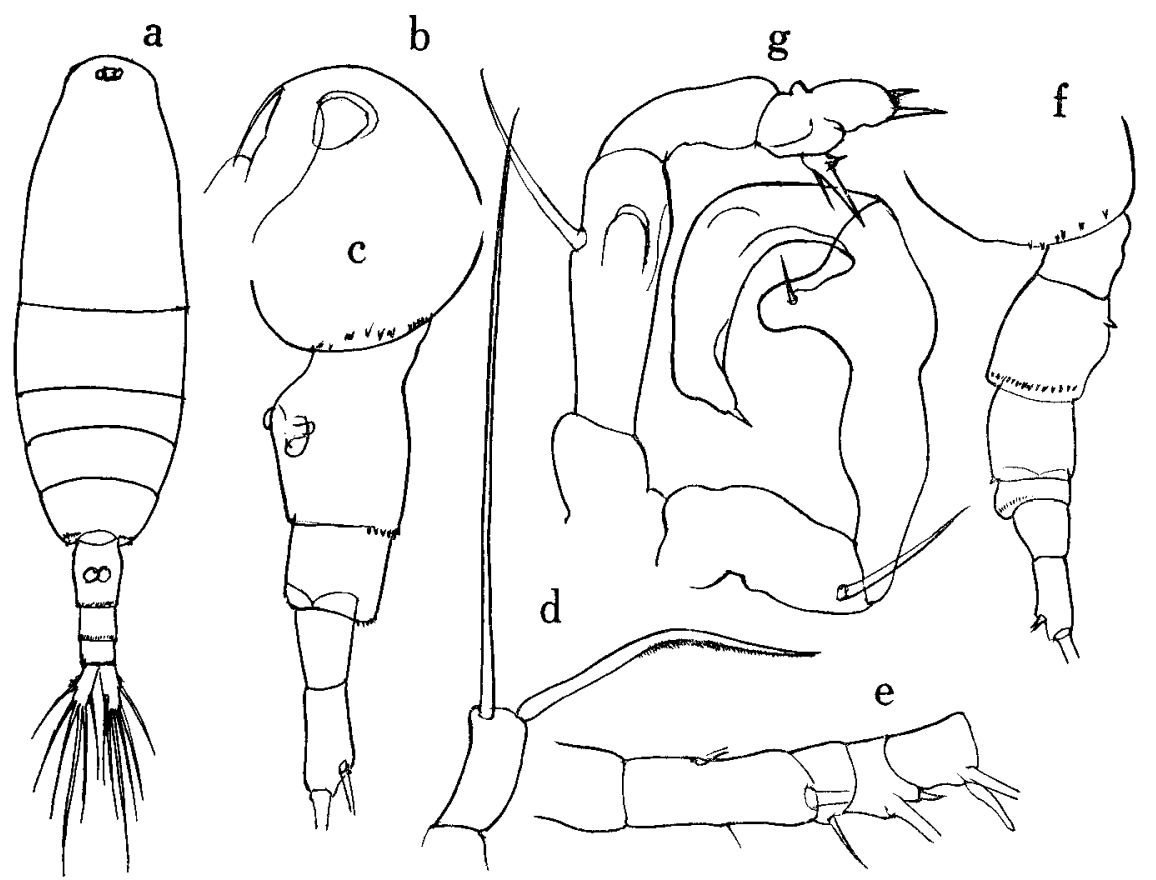

Fig. 245. Acartia steueri SMIRNov.

Female: $a$, dorsal aspect; $b$, head, lateral aspect; $c$, last thoracic segment and abdomen, lateral aspect; d, 5th leg; e, proximal portion of 1st antenna. Male: $\mathrm{f}$, last thoracic segment and abdomen, lateral aspect; $g$, 5th pair of legs.

and is spinulose only along the inner margin; the outer edge seta very long and slender.

Male. Length, $1.13-1.25 \mathrm{~mm}$. The general appearance as in the female. The abdominal segments and furca are in the proportional lengths measured in $0.01 \mathrm{~mm}$ as $5,9,7,2,5$ and 6 ; the 2 nd abdominal segment has 2 spinules near the ventral proximal margin; this is not observed by SMIRNov.

The right 1st antenna has no denticles on the anterior margin of the segment 18. In the 5th pair of legs the exopod of the right leg rather simple 
in structure: the 1st segment of the exopod has no spines on the inner proximal margin; the 2nd segment has a large protuberance furnished with a spine on the apex; the distal segment is long and curved, with a small spine on the apex. In the left leg the 2 nd baasal segment 3 time as long as wide and has a protuberance about the middle of the segment; the 1st segment of the exopod about 2 times as long as wide; the last segment of the exopod has a large and strong spine at the proximal inner margin, to which 2 small spines are attached at the proximal part of the spine; the apex of the distal segment carries 2 spines, of which the inner one longer; the outer margin of the segment has a small protuberance near the proximal part.

Occurrence. Five females and two males from the surface in February, 1936.

Distribution. The species has been recorded from the northern part of the Japan Sea near Wladiwostok and far-eastern and polar seas of the USSR.

\section{Acartia (Odontacartia) amboinensis CARL.}

(Fig. 246, a-d)

Acartia amboinensis, STEUeR, 1923, p. 120, figs. 151-6; SEWELL, 1932, p. 396.

Female. Length, $1.34-1.51 \mathrm{~mm}$. The last thoracic segment produced into a strong spine on each side laterally and has 2 small spines on the dorso-lateral corner. The abdomen 3 jointed ; the segments and furca are in the proportional lengths as $54: 18: 7: 21=100$; the genital segment has 2 spines on the dorsal distal margin; the 2 nd segment has 4 very minute spinules. The furcal rami as long as wide.

In the 1st antenna the 1st segment has, beside 2 strong spines, a very minute one on the posterior margin; the 2nd segment has 4 minute spines on the posterior margin and a moderate one in the distal posterior margin; the 3rd and 4th segments have each a spine on the posterior distal margin; the 5 th segment has 2 small spines.

In the 5th pair of legs the middle segment narrow, 3 times as long as wide; the terminal claw has 2 slight swellings near the proximal and bends abruptly inwards at the distal half; the claw is 2 times as long as the middle segment. The feathered seta is 3 times as long as the middle segment.

Remarks. The specimen, at the first sight, resembles A. erythraea, A. australis Farran, A. pitschmanii Pesta and A. bispinosa Carl. But specimen differs from A. erythraea in the armature of the 2 nd abdominal segment; the present specimen has 4 spinules on the dorsal distal margin of the 2 nd abdominal segment; in the 1st antenna the armature of the 2 nd and 4 th segments differs from those of erythraea; the 5th pair of legs resembles well that of erythraea but the middle joint is longer in the present specimen; the claw-like spine is more swollen 


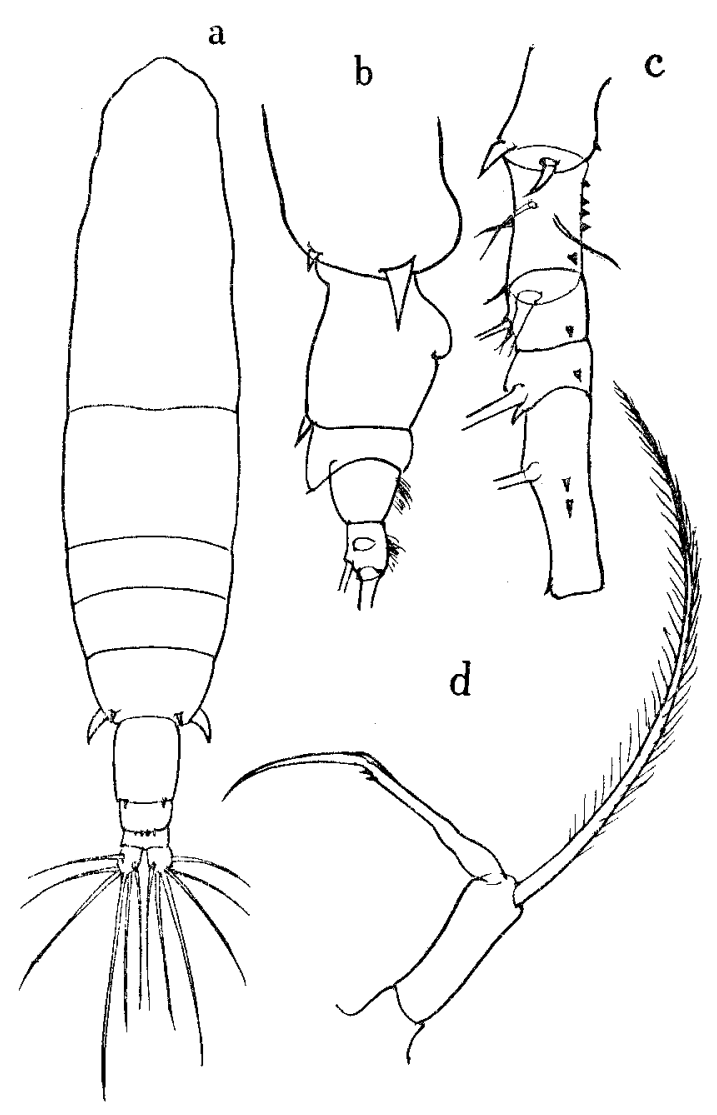

Fig. 246. Acartia amboinensis CARL.

Female : a, dorsal aspect ; b, last thoracic segment and abdomen, lateral aspect; c, proximal portion of 1st antenna ; d, 5th leg. at the proximal in erythraea. The specimen comes near to australis but can be distinguished from it in the armature of the 2nd abdominal segment and in the spinulation of the 1 st and 2nd joints of the 1st antenna; the 5 th pair of legs of the present specimen resembles that of australis but the basal segment is longer in the present specimen. The specimen comes closest to pitschemanni but in the present specimen the lateral spine of the last thoracic segment is small. The 3rd abdominal segment and furcal rami have each a tuft of hairs on the ventral margin in the present specimen; the 5 th pair of legs differs from that of pitschemanni in having a curved claw, whereas, it is rather straight in pitschemanni. The specimen differs from bispinosa in the armature of the 2nd segment of the 1st antenna; in bispinosa according to SeweLL (1914) the 2nd segment has a

large curved spine on the posterior margin; the external seta of the 5th leg is very short in bispinosa. The specimen is also closely related $A$. japonica MORI but differs from the latter in the proportional lengths of the furca, the spinulation on the dorsal distal margin of the 2nd abdominal segment, and in the proportional lengths of the claw to the middle segment which is much longer in japonica.

Occurrence. Three females in winter, 1935.

Distribution. The species has been recorded from the Indian seas.

Acartia (Odontacartia) pacifica SteUER.

(Fig. 247, a-f) 
Acartia pacifica, SteUer, 1923, p. 28, figs. 134-137 ; SEWELl, 1932, p. 397 ; FARRAN, 1936, p. 120 ; BroDSKY, 1950, p. 422, text-fig. 298.

Female. Length, $1.23 \mathrm{~mm}$. The lateral corner of the last thoracic segment produced laterally on each side into a strong spine; the dorsal surface of the segment is furnished with a pair of 2 small spines near the distal margin, STEUER's specimen has a pair of single spine instead of two.

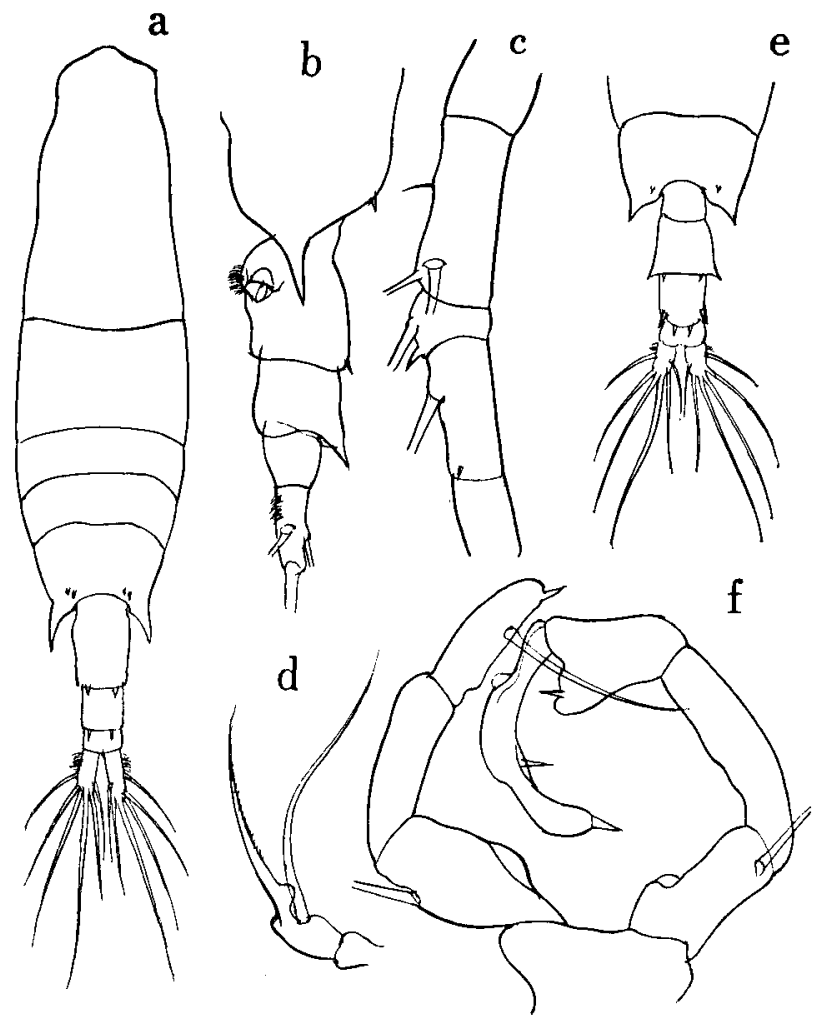

Fig. 247. Acartia pacifica Steuer.

Female: $a$, dorsal aspect; $b$, last thoracic segment and abdomen, lateral aspect; $c$, proximal portion of 1st antenna ; d, 5th leg. Male: e, last thoracic segment and abdomen, dorsal aspect; f, 5th pair of legs.

The abdominal segments and furca are in the proportional lengths as $43: 21: 15: 21=100$; the 1st and 2 nd segments have each 2 spines on the dorsal distal margin; a tuft of hairs is observed on the ventral surface of the genital segment about the periphery of the genital opening.

In the 1st antenna the 1st and 2nd segments has no spines. The 5th pair of legs has a small protuberance on the inner proximal margin of the terminal claw, the outer marginal seta longer than the claw. 
Male. Length, $1.23 \mathrm{~mm}$. The last thoracic segment terminates into a strong spine on each side; the postero-dorsal margin is furnished with a small spine on each side of the segment. In the abdomen the 2nd, 3rd and 4th segments have each a pair of spines on the dorsal distal margin; the ventral surface of the 2nd segment is provided with 3 rows of fine hairs, the lateral margin of the segment with a small spine on each side.

In the right 1st antenna the segments 13 and 14 are finely serrated on the anterior margin. The 5 th pair of legs agrees with STEUER's figure except that there is no spine on the inner distal margin of the 1st segment of the exopod of the right leg; the spine might have been lost in the present specimen.

Remarks. A single male specimen measured $1.15 \mathrm{~mm}$ had a lateral thoracic spine divided into to 2 at the apex on the left side. This may be abnormal.

Occurrence. One female and two males in winter, 1935.

Distribution. The species has been recorded from the Pacific, $32^{\circ} \mathrm{N}, 157^{\circ} \mathrm{W}$, Indian seas, Great Barrier Reef Sea and from the far-eastern and polar seas of the USSR.

\section{Acartia (Planktacartia) \\ danae GiesBracht.}

(Fig. 246, a-e)

Acartia danae, GIESBRECHT, 1892, p. 508, t. 30 , figs. $5,19,32 ;$ t. 43 , figs. 12,13 ; A. SCOTT, 1909, p. 187; Sato, 1913, p. 40; Steuer, 1923, p. 123 ; FARRAN, 1929, p. 282 ; SEWELL, 1932, p. 397 ; FARRAN, 1936, p. 122 ; MORI, 1937, p. 102, pl. 49, figs. 5-15; WiLSON, 1950, p. 151.

Female. Length, $1.17-1.27 \mathrm{~mm}$. The lateral corner of the last thoracic segment produced into a strong spine. The last thoracic segment has no rows of fine spinules on the dorsal surface in the present specimen, though Steuer observed these spinules in the "Valdivia" specimen. The genital segment, has 4 minute spines on the dorsal margin; the 2nd segment has 2 minute spinules.

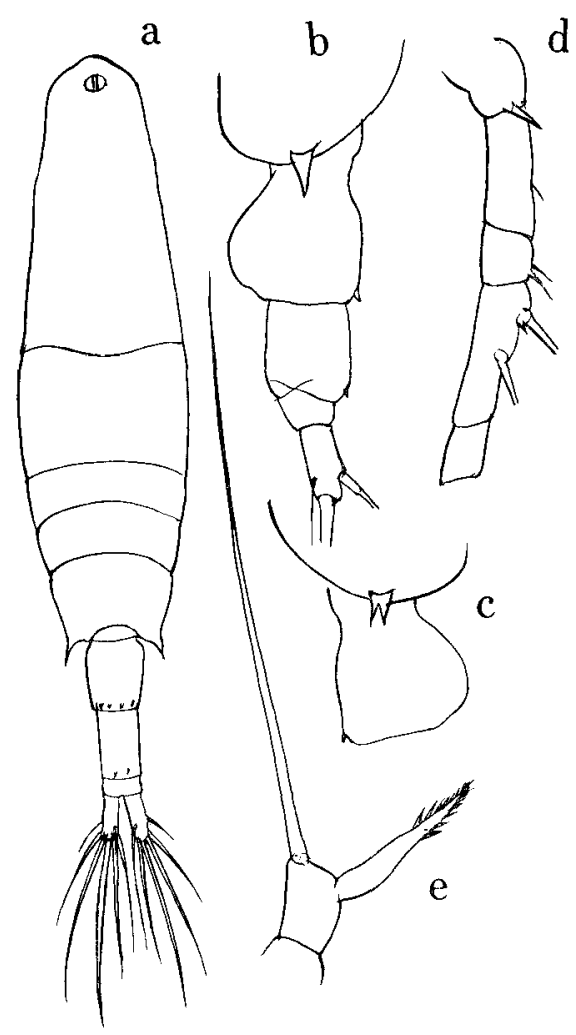

Fig. 248. Acartia danae GIEsbrechr. Female: $a$, dorsal aspect; b, last thoracic segment and abdomen, lateral aspect; c, last thoracic segment, lateral aspect, another specimen; d, proximal portion of 1st antenna; e, 5th leg. 
The 5th pair of legs has a comparatively wide basal segment; the terminal claw is coarsely dentate on each side; the outer marginal seta long and slender.

In some specimens (length, 1.27 and $1.30 \mathrm{~mm}$ ) the lateral corner of the last thoracic segment has a thoracic spine divided into two on the right side.

Occurrence. Nine females in winter, 1935.

Distribution. The species has a wide distribution in the Pacific, Atlantic and Indian Oceans.

\section{Acartia (Planktacartia) negligens DANA.}

(Fig. 249, a-g)

Acartia negligens, GiesbRecht, 1892, p. 508, t. 30 fig. 22 ; t. 43, fig. 18 ; A. ScotT, 1909, p. 188; SteUter, 1923, p. 123; FARRAN, 1929, p. 281; 1936, p. 122 ; MORI, 1937, p. 101, pl. 49, figs. 1-4; WILSON, 1950, p. 155.

Female. Length, $1.09-1.20 \mathrm{~mm}$. The last thoracic segment rounded and has
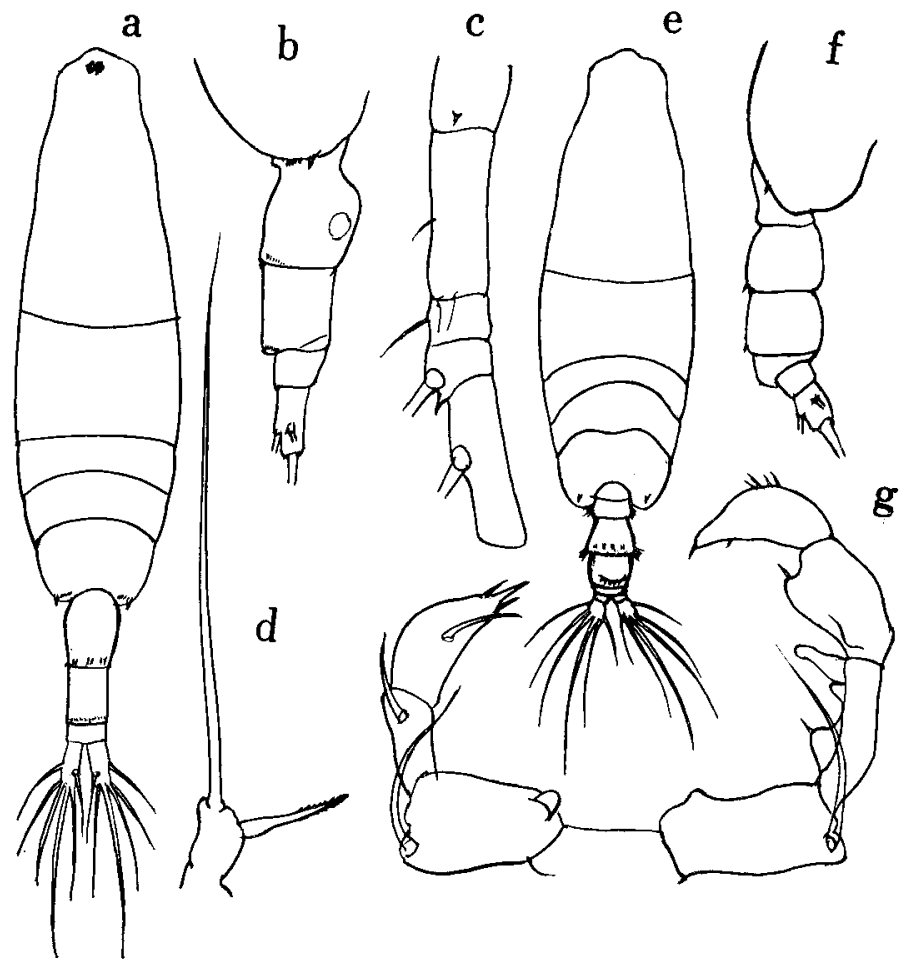

Fig. 249. Acartia negligens GIESBRECHT.

Female : a, dorsal aspect; b, last thoracic segment and abdomen, lateral aspect; c, proximal portion of 1st antenna; d, 5th leg. Male: e, dorsal aspect; $f$, last thoracic segment and abdomen, lateral aspect; g, 5th pair of legs. 
a small lateral spine and a row of minute spinules on the lateral distal corner; the spine appears to be variable in number, it is sometimes 2 or 3 . The 1st and 2nd abdominal segments are furnished with minute spinules on the dorsal distal margin. The furcal ramus 2 times as long as wide.

In the 1st antenna the 1st segment has a small spine on the distal margin. In the 5th pair of legs the terminal claw short and finely dentate; the outer marginal seta slender and long; the middle segment about 1.4 times as long as wide.

Male. Length, 0.946. The last thoracic segment round with a small spine on each side of the dorso-lateral margin. In the abdomen the 1st segment has a tuft of short hairs on each side of the lateral margin; the 2nd segment has, beside the tuft of hairs on the lateral distal margin, a row of minute spinules on the dorsal distal margin; the 3rd segment has 4 minute spinules near the dorsal distal margins. The furcal ramus about as long as wide.

The right 1st antenna has fine serrations on the anterior margin of the segments 18 and 19-21. The 5th pair of legs agree well with STEUER's figure; the 1st segment of the exopod of the left leg has a long outgrowth on the inner distal margin; in the right leg the 2nd basal segment has a rounded process on the inner proximal corner.

Occurrence. Nine females and one male in winter 1935.

Distribution. The species has a wide distribution in the warm regions of the Atlantic, Pacific and Indian Oceans and also in the Mediterranean Sea.

\section{Family TORTANIDAE}

\section{Genus Tortanus GiEsBRechT.}

A. Scotr in the account of the copepods of the "Siboga" recorded the occurrence of Tortanus barbatus (BRADY), T. gracilis (BRADY), T. brevipes A. SCOTT and T. murrayi A. Scotr. Sewell (1932) recorded the following specimens from the Indian seas: $T$. gracilis, $T$. forcipatus Giesbrecht, $T$. barbatus and T. tropicus Sewell. He divided the genus Tortanus into two subgenera, Tortanus and Atortus; to the former belong $T$. forcipatus, T. barbatus and $T$. gracilis; to the latter belong $T$. brevipes, T. recticauda (GIESBREcht), T. murrayi and T.tropicus. From the Japanese waters MORI recorded $T$. forcipatus, and $T$. discaudatus, (Thomson and A. ScotT). BRodsky (1950) recorded the occurrence of T. discaudatus, $T$. derjungini SMIRnov and the male of T. longipes Bronsky from the far-eastern and polar seas of the USSR, among which T. longipes is identical with the specimen listed by me under the name $T$. steueri sp. nov. in "The pelagic copepods of the Izu region". T. derjungini SMrRnov has been recorded from the Japan Sea and Okotsk Sea. The species was found by me from the Ariake Sea, a large and shallow inland sea of the north-western coast of 
Kyushu. From the Izu region the following species have been detected: $T$. forciprtus, T. longipes and T. rubidus; the last one appears to be new to science.

\section{Tortanus forcipatus (GIESBRECHT).}

Corynura forcipatus, GIESBRECHT, 1892, p. 525, t. 31, 42; Tortanus forcipatus, ThOMPSON and A. ScotT, 1903, p. 254 ; STeuer, 1926, p. 60 ; Sewell, 1932, p. 399 ; Mori, 1937, p. 105, p. 51, figs. $11-14$.

Female. Length, $1.09 \mathrm{~mm}$. The cephalothorax $0.75 \mathrm{~mm}$; abdomen, $0.34 \mathrm{~mm}$. The last 2 thoracic segments separated. The lateral corner of the last thoracic segment bluntly round. The abdomen 3 -jointed; the anal segment and furca asymmetrical. The furcal rami long and twisted.

The 1st antenna 17-jointed, extends to the middle of the furca. The 5 th pair of legs asymmetrical; in the left leg the terminal segment elongated, 2 times as long as that of the right leg and carries 2 small outer marginal spines; the distal segment of the right leg has 3 small outer marginal spines.

Occurrence. One female in November, 1935 from the surface layer.

Distribution. The species is widely distributed in the Malay Archipelago, Red Sea and northern part of the Indian Ocean.

\section{Tortanus longipes BRODSKY.}

(Fig. 250, a-k)

Tortanus longipes, Brodsky, 1950, p. 433, text-fig. 306 (male)； T. steueri, TANAKA, 1953, p. 137.

Female. Length, $2.55 \mathrm{~mm}$ : cephalothorax, $1.96 \mathrm{~mm}$; abdomen, $0.59 \mathrm{~mm}$. The cephalothorax oblong ovate and moderately robust. The head is separated from the 1st thoracic segment; the last 2 segments completely fused. The last thoracic segment quite asymmetrical; the left side irregularly sinuate at the lateral margin; the right side is rounded and slightly produced posteriorly on the distal margin. There is a small triangular process beneath the large eye when viewed from the lateral.

The abdomen 2 -jointed. The genital segment asymmetrical; the lateral margin more inflated on the left side. The anal segment fused with the furca. The furcal rami asymmetrical; the left ramus is broader; the 2nd furcal seta broad at the proximal. The adbomen was covered with lamellous plates in the present specimen.

The 1st antenna 15-jointed extends to the end of the furca; the 2nd segment has a small spine on the anterior distal corner; the 3rd segment long, carries 2 small spines on the anterior margin and a spine on the anterior distal margin. The mouth parts as those of the foregoing species. The 
maxilliped as in $T$. recticauda (GIEsBRecht).

The 5 th pair of legs is similar in structure to that of T. brevipes A. ScotT; the basal segment is broad; the distal segment rounded in shape carries a an outer marginal seta which is slightly shorter than the distal segment; a slight knotch is found on the posterior surface about the middle of the segment.

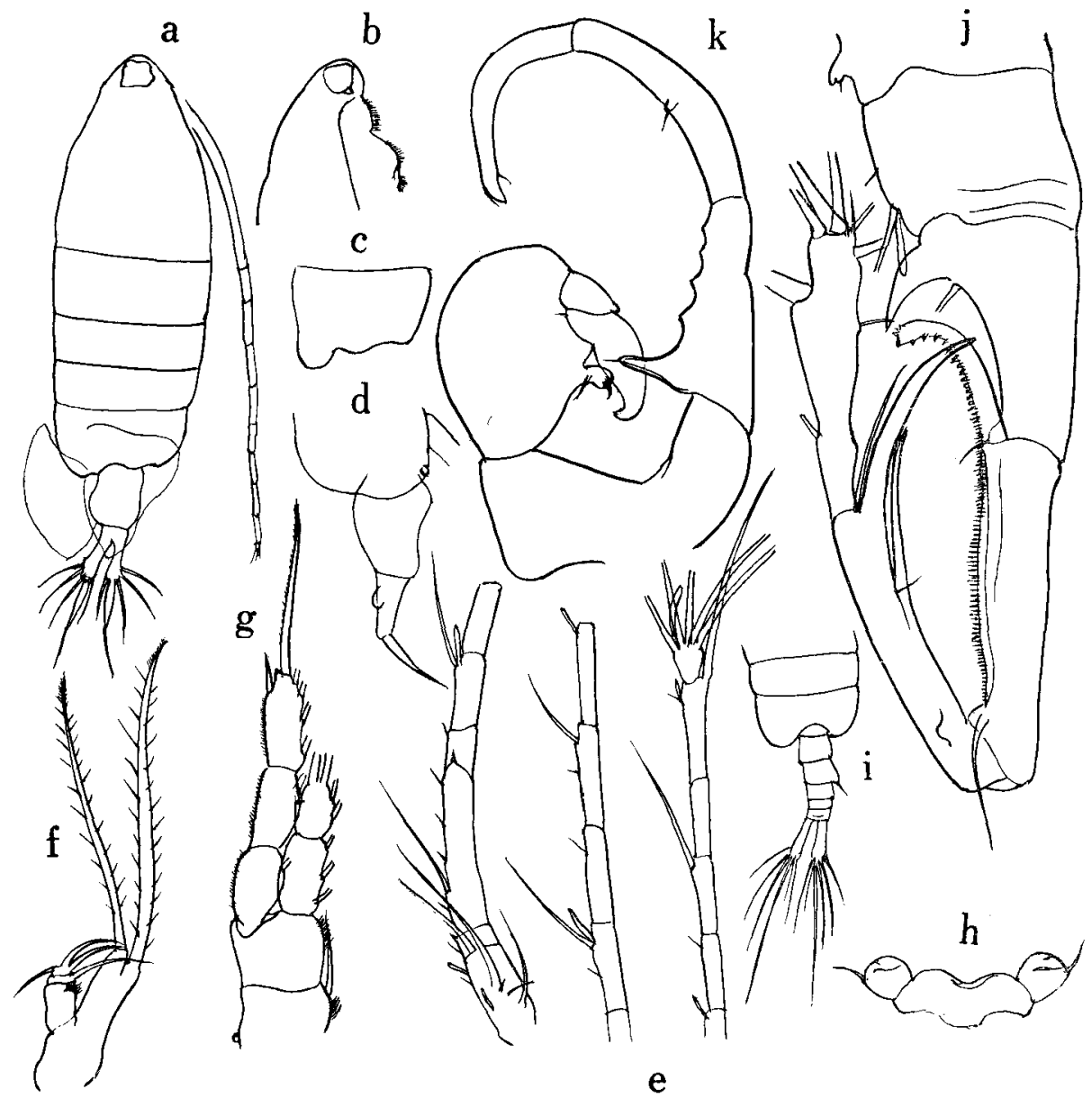

Fig. 250. Tortanus longipes BRODSKY.

Female : a, dorsal aspect; b, head, lateral aspect; c, last thoracic segment, lateral aspect, left side; d, last thoracic segment and abdomen, lateral aspect, right side; e, 1st antenna ; $f$, maxilliped; $g$, 1st leg; $h$, 5 th pair of legs. Male : $i$, thoracic segments and abdomen, dorsal aspect; $\mathbf{j}$, clasping antenna; $\mathbf{k}$, 5th pair of legs.

Male. Length, $2.40 \mathrm{~mm}$ : cephalothorax, $1.68 \mathrm{~mm}$; abdomen, $0.72 \mathrm{~mm}$. The male has a general resemblance to the female. The last thoracic segment slightly asymmetrical; the lateral corner produced posteriorly in a obtuse angle.

The abdomen 5-jointed; the segments are in the proportional lengths as 
$12: 19: 16: 15: 11: 31=100$. The 2 nd segment has a spine on the lateral distal margin and a very small one the ventral distal margin.

In the 1st antenna the middle section of the right antenna much inflated; the segment 15 has a peculiar process on the distal corner of the anterior margin; the segment 17 has a strong spine on the anterior proximal margin; the segment 18 is furnished with a spur-shaped process extending proximally about to the proximal $1 / 3$ of the 17 th segment, the anterior margin of the process is coarsely serrated; the segment 19 has 2 strong spines, the one about the middle of the segment, the another on the distal upper margin of the segment. The left antenna as in the female.

The 1st to 4th legs are similar to those of the female. The 5th apir of legs large; the right leg is composed of 2 free segments attached to 1 -jointed basal; the 1st segment of the exopod bears a rounded process on the inner margin about the middle, the 2nd segment is claw-like, bears 2 inner marginal setae. The left leg composed of 3 free segments attached to the 1 -jointed basal; the 1st free segment is strongly sinuate on the inner margin, the proximal process is the largest and carries a fine seta on the apex; the 2nd segment long and curved and is furnished with a small process bearing a seta about the middle of the inner margin; the distal segment shorter than the preceding segment and has 2 small spines near the apex, and a tuft of hairs on the inner proximal margin.

Remarks. Brodsky recorded only male specimens measuring $2.06 \mathrm{~mm}$ from the far-eastern sea of the USSR.

Occurrence. One female and a male from Misaki, November 1933 and a male from the same region in October 1936.

Distribution. The species has been recorded from the Japan Sea, Okotsk Sea and Aburatsubo, a small inlet of Sagami Bay where the Marine Biological Station of the Tokyo University stands.

\section{Tortanus rubidus sp. nov.}

(Fig. 251, a-f)

Male. Length, $2.09 \mathrm{~mm}-2.30 \mathrm{~mm}$. The specimen resembles the male of $T$. longipes Brodsky. The abdomen is contained 2.9 times in the length of the cephalothorax. The last thoracic segment symmetrical. The abdomen is composed of 5 segments; the segments and furca are in the proportional lengths as $20: 16: 13: 9: 7: 35=100$; the 2nd segment has two spines, the one on the right lateral distal corner, the another on the ventral distal margin.

The crasping antenna is of the same structure as in $T$. longipes but the process on the anterior margin of the segments 17 and 18 are slender. The left antenna 15-jointed, extends to the end of the abdomen. The mouth parts 
and swimming legs are similar to those of $T$. longipes. The 5 th pair of legs is similar in structure to that of $T$. murrayi A. ScotT; in the right leg the basal segment has a large process on the inner distal margin; the 1st segment of the exopod has a large process complicated in structure on the middle of the inner margin; the distal segment about as long as the preceding segment, has 2 inner marginal setae and an outer marginal seta. In the left leg the 1st segment of the exopod long and carries a seta on the outer margin, the inner margin has a small tubercle furnished with a small seta on the apex; the 2nd segment has a process on the inner proximal margin; the distal segment

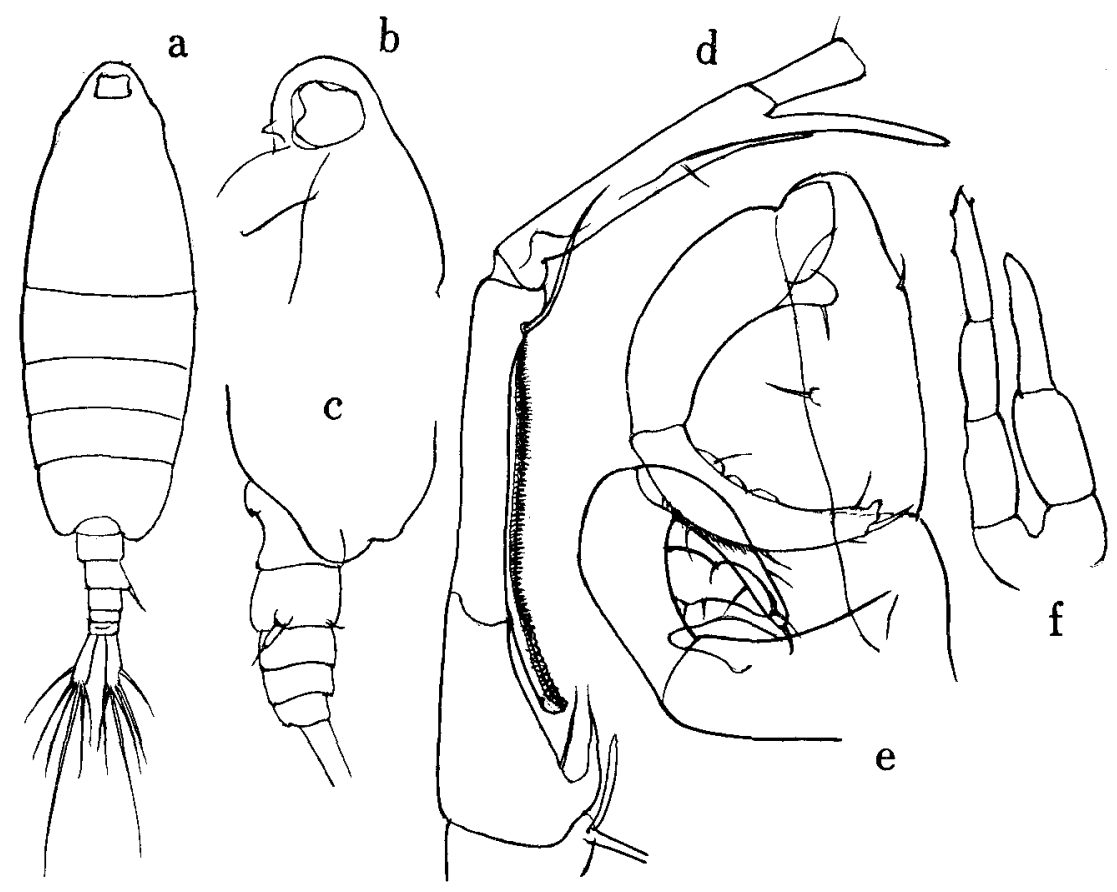

Fig. 251. Tortanus rubidus sp. nov.

Male: a, dorsal aspect; b, head, lateral aspect; $c$, last thoracic segment and abdomen, lateral aspect; $d$, middle portion of clasping antenna; $e, 5$ th pair of legs. Male, juv.: $f$, 5 th pair of legs.

has several lamellous plates along the inner margin, the outer margin of the segment is furnished with short hairs and 2 small spines, the apex of the segment ends in a papilla and has a large spine on the outer distal corner and a smaller one on the inner distal corner.

Immature male. Length, $1.73-1.95 \mathrm{~mm}$. The immature specimen has 4jointed abdomen. The right 5 th leg has 2 free segments; the left leg has 3 segments attached to the basal.

Remarks. The present specimen is closely allied to $T$. longipes BRoDSky 
but the species can be easily distinguished from the later by the shape of the 5th pair of legs.

Occurrnece. Five adult males and two immature males from Misaki, a small inlet of Sagami Bay, in a surface collection.

Distribution. Sagami Bay (present record).

\section{LITERATURE CITED}

(from I to XIII)

ANRAKU, M. 1952. Plankton copepods collected by R.S. "Yushio-Maru" in Pacific waters to the east of northern Japan during her cruise in Nomber, 1948. Bull. of the Faculty of Fisheries, Hokkaido, University, 3 (1), 21-39.

- 1954a. Copepods collected on the whaling grounds off northern Japan and Bonin Islands. Ibids., $5(\mathbf{1}), 1-8$.

1954b. Gymnoplean copepods collected in Aleutian waters in 1955. Ibid., 5 (2), 123-136.

Bogorov, B. G. 1957a. Unification of plankton research. Colloque international de Biologie marine station biologique de Roscoff. Anné Biologique T. 33, Fasc. 7-8, 299-315.

157b. Regularties of plankton distribution in the North-west Pacific. Proc. UNESCO Symp. phys. oceanogr. Tokyo, 1955, 260-270.

Bowman, T. E. 1955. A new copepod of the genus Calanus from the northeastern Pacific with notes on Calanus tenuicornis DANA. Pacific Science, (9), 413-422.

1957. A new species of Calanopia (Copepoda: Calanoida) from the Caribbean Sea. Proc. U. S. National Mus., 107 (3382), 39-45.

1958. A new species of Acrocalanus (Copepoda: Copepoda) from off the southeastern coast of the United States. Bull. Maine Science the Gulf and Garibbean, 8 (2), 118-124.

BRADY, G. S. 1883. Report on the Copepoda collected by H. M. S. Challenger during the years 1873-76. Report on the Scientific Results of H. M. S. Challenger, Zoology, Vol. 8, Pt. 1, 1-142.

Breemen, J. van 1908. Copepoden. Nordisches Plankton. Zool. Teil, Bd. 4. Entomostraca VIII, $1-264$.

Brodsky, K. A. 1950. Calanoida of polar and far-eastern seas of the U.S.S. R. Opredeliteli po Fauna S. S. R. R., Izdavaemi, Zoologicheskim Institutom Akademii Nauk, S. S. S. R. 35, 1-442. (In Russian)

- 1952. On the vertical distribution of copepods in the northwestern Pacific Ocean. Investigations of the far-eastern seas of the USSR III. Deep water fauna of the northwestern Pacific Ocean. (Translated by W. G. VAN CAMPEN, 1956, U. S. Fish and Wildlife Service, Special Scientific Report-Fisheries No. 192, 1-6.

1959. Zooplankton of sea waters of south Sahkalin and south Kurile Islands. Investigations of Far-eastern Seas VI. Academy of Science, U.S. R., 5-46. (In Russian)

CAMPBELL, M. H. 1929. Some free-swimming copepods of the Vancouver Island region. Transaction of the Royal Society of Canada 23, pt. 3, sect. 5, 303-332.

CANNICCI, G. 1960. Consederazioni sulla possibelità di stabilite "inducatori ecologici" nel plancton del Mediterrane-Estratto dal Bolletino pesca, Piscicolture e idrobiologia. Anno XXXV, Vol. XIV (n. s.), Fasc. 2, 164-188.

CHIBA, T. 1949. On the distribution in the eastern China Sea and Yellow sea. I. Plankton composition in spring. The Journ. Shimonoseki College of Fisheries, I (1), 57-63.

1952a. On the distribution of the plankton in the eastern China Sea and Yellow Sea. II. Obsevations on the plankton in spring during the period 1949-50. Bulletin of the Japanese Society of Scientifc Fisheries, 17 (7), 183-186. (In Japanese.) 
ChibA, T. 1952b. On the distribution of the plankton in the eastern China Sea and Yellow Sea III. Obesrvations on the plankton in autumn during the years 1948-1949. Ibid. (7), $187-190$.

1953. Studies on the pelagic Copepoda from the Japan Sea. I. On the genus Euchaeta Philippi, 1843. Ibid., 18 (11). 613-617.

1956. Studies on the development and systematics of Copepoda. The Jour. Shimonoseki Coll. Fish., 6 (1). 1-90. (In Japanse)

ChibA, T., and A. Tsuruta 1955. On the plankton in the western sea region of Sunda Islands. Ibid., 4 (1), 83-94. (In Japanese).

ChibA, T., A. Tsurta and H. MAEdA 1955. Report on zooplankton samples hauled by larvanet during the cruise of Bikini-Expedition, with special reference to copepods. Ibid. 5 (3), $189-213$.

Chiba, T., T. Satow, A. Tsuruta, O. Hirano and S. TAgawa 1957. Oceanographical and planktological studies in the Tuna fishing grounds in the middle part of the North Indian Ocean. Ibid., 6 (5), 291-313.

Claus, C. 1863. Die freilebenden Copepoden. Leipzig.

Crisafr, P. 1963. I copepodi dello stretto di Messina. Atti della Società dí Scienze matematiche e naturali, 9 (fasc. I/II), 81-143.

DAHL, F. 1894. Über die horizontal und vertikalen Verbreitung der Copepoden im Ozean. Verhandlung der deutschen Zoologischen Gesellschaft, Vol. 4, 61-80, 4 text-figures.

DAvis, C. C. 1949. Pelagic Copepoda of the northeastern Pacific Ocean. University of Washington Publications in Zoology. Vol. 14, 1-117.

Defvey, G. B. 1952. Quantity and composition of the zooplankton of Block Island Sound, 1949. Bull. Bingham Oceanogr. Coll. Vol. XIII (3), 121-164.

1952b. A survey of the zooplankton of Block Island Sound, 1943-1946. Ibid. Vol. XIII (3), 65-119.

1960. Plankton Studies. The zooplankton of the surface waters of the Delaware

Bay region. Bulletin of the Bingham Oceanographic collection, Peabody Museum of Natural History Yale University Vol. 17, Article 2, 1-86.

EkMAN, S. 1935. Tiergeographie des Meeres. Leipzig.

Elda FAgetTI, G. 1962. Catalogo de los Copépods planctönicos Chilenos. Gayana Instituto central de Biologie, Zoologia, No. 4, 1-59.

Esterly, C. C. 1905. The pelagic Copepoda of the San Diego region. University of California Publications in Zoology. 2 (4), 113-233.

1906. Additions to the copepod fauna of the San Diego region. Ibid., 3 (5), 53-92. 1911. Third report on the Copepoda of the San Diego region Ibid., 6 (14), 313-352.

1913. Fourth taxonomic report on the Copepoda of the San Diego region. Ibid., 11 (10), 181-196.

1924. The free swimming Copepoda of San Francisco Bay. Ibid., 26 (5), pp. 81-129.

FARRAN, G. P. 1901. Record of the Copepoda taken on the Mackerel fishing ground off Cleggan in 1901. Appendix no. VII to Part II of the report on the on the sea and Inland fisheries of Ireland for the year 1901. Appendix, No. VII, 1-18.

- 1905. Report on the Copepoda of the Atlantic Slope off Counties Mayo and Galway. Fisheries Ireland Sci. Invest., 1902-1903. Pt. 2, Appendix, 2, 23-52.

1908. Second report on the Copepoda of the Irish Atlantic Slope. Ibid. 1906, Pt. 2, 1-104.

1926. Biscayan plankton collected during a cruise of H. M. S. "Research" 1900. Pt. XIV. The Copepoda. Jour. Linn. Soc. Zoology, Vol. XXXVI, 219-310.

1929. Crustacea Pt. X. Copepoda. British Antarctic "Terra Nova" Expedition, 1910.

Natural History. Zoology, Vol. VIII, No. 3, 203-306. 
Farran, G. P. 1936. Copepoda. Great Barrier Reef Expedition 1928-29. Scientific Reports. 5 (3), $73-142$.

Fleminger, A. 1957a. New calanoid copepods of Pontella DANA and Labidocera Lubbock with notes on the distribution of the genera in the Gulf of Mexico. Tulane studies in Zoology. $5(2), 19-34$.

1957b. New genus and two new species of Tharybidae (Copepoda Calanoida) from the Gulf of Mexico with remarks on the status of the family. Fishery Bulletin 116, Vol. 57, 347-354.

1957c. New calanoid copepods of the families Aetideidae, Euchaetidae, Stephidae from the Gulf of Mexico. Ibid. 117, Vol. 57, 355-363.

Fleminger, A., and T. E. Bowman 1956. A new species of Candacia (Copepoda: Calanoida) from the western north Atlantic Ocean. Proc. U.S. National Mus. 106 (3370), 331-337.

FRÜchtL, F. 1920. Planktoncopepoden aus der nördlichen Adria. Sitzungsberichten der Akademie der Wissenschaften in Wien, Mathem-naturw, Klasse, Abteilung I, 129 (9), 1-47.

1923a. Notizen über die Variabilität nordadriatischer Planktoncopepoden. Verhandlungen der Zoologisch-Botanischen Gesellschaft in Wien, 73, 135-157.

1932b. Cladocera und Copepoda der Aru-Inseln. Abhandlungen der Senckenbergischen Naturforschenden Gesellschaft, 37 (4), 449-457.

1924a. Beitrag zur Kenntnis der qualitative und quqntitativen Verbreitung nordadriatischer Planktoncopepoden und ihrer Epibionten. Sitzungscerichten der Akademie der Wissenschaften in Wien, Mathem-naturw. Klasse, Abteilung I, 132 (7 und 8), 195-223.

1924b. Cladocera und Copepoden Fauna der Aru-Archipelagos, Mit Beiträgen zur strulturellen Anomalien indo-pazifischer Planktoncoyeträgen zur strulturellen Anomalien indopazifischer Planktoncopepoden. Arbeiten aud der Zoolog. Inst. Univ. Innsbruck 2 (2). 1-114. 1934. Beitrag zur Kenntnis der Missbildungen adriatischer Planktoncopepoden. Sitzungsberichten der Akademie der Wissenschaften in Wien, Mathem-naturw. Klasse, Abteilung I, 143 ( 5 bis 7 ), $147-157$.

FUkAse, S. 1957. Note on a variety of Eucalanus subtenuis GIESBREcht from the Japansese waters. Jour. Oceanogr. Soc. Japan. 13 (1). 17-21.

FuruhashI, K. 1952. Notes on some animal palnktons collected from the sea of Japan off San'in district. Publ. Seto Mar. Biol. Lab. II (2), 257-260.

1955. Notes on some animal plankton collected from the deep layer of the Pacific waters off southern Japan. Umi to Sora, Vol. 31. (In Japanese)

1961a. On the distribution of some plankton animals in Kuroshio region south of

Honshu, Japan, with notes on the nature and origin of the cold water mass appearing in the region. Ibid. $37(2), 15-27$.

-1961b. On the distribution of some plankton animals in the Kuroshio region south of Honshu, Japan, with notes on the nature and origin of the cold water mass appearing in the region. Ibid. 37 (3), 9-16.

1961c. On the distribution of some plankton animals in the Kuroshio region south of Honshu, Japan, withe notes on the nature and origin of the cold water mass appearing in the region. Ibid. 37 (4), 4-15.

1964d. On the possible segregation found in the copepod fauna in the deep waters off the southeastern coast of Japan (JEDS-3). Publ. Seto Mar. Biol. Lab., Vol. IX (1), 1-15.

Furuhashi, K., and Y. MATSudaira 1960. On the vertical distribution of pelagic Copepoda collected from the Kurosio region south of Honshu. Memoirs of the Kobe Marine Observatory, Vol. 14.

Giesbrecht, W. 1892. Systematik und Faunistik der pelagischen Copepoden des Golfes von Neapel. Fauna und Flora des Golfes von Neapel u.d. abgrenzenden Meeresabschnitte, 19, 1-831. 1896. Über pelagischen Copepoden des Rothen Meere, gesammelt vom Marinestabarzt Dr. Augustin Krämer. Zool. Jahrb., Abt. Systematik, 9, 315-327. 
Gresbrecht, W. 1902. Copepoden. Resultats de Voyage du S. Y. "Belgica" du 1897-1899. Rapports Scientifique. Zoologie. 1-49.

GIESbrecht und SchmeIl 1898. Copepoda I. Gymmoplea, Das Tierreich. Lief. 6.

GRICE, G. D. 1959. A new species of Haloptilus (Copepoda : Calanoida) from equatorial and subtropical waters of the east-central Pacific Ocean. Jour. Washington Academy of Science, 49 (6), 193-195.

1960a. Calanoida and Cyclopoida copepods collected from the Florida Gulf coast and Florida Keye in 1954 and 1955. Bulletin of Marine Scienc of the Gulf and Caribbean, vol. $10(2), 217-226$.

- 1960b. Copepods of the genus Oithona from the Gulf of Mexico. Ibid. 10 (4).

1961. Candacia ketchumi, a new Calanoidd copepod from the north-western part of the Sargasso Sea. Crustaceana $2(2)$, 126-131.

1962a. Calanoid copepods from equatorial waters of the Pacific Ocean. Fish. Bull. Fish Wildlife sevides, 61, 171-241.

- 1962b. Copepods collected by the nuclear submarine Seadragon on a cruise to and from the North Pole, with remarks on their geographic distribution. Jour. Mar. Research, 20 (1), 97-109.

- 1963a. A revision of the genus Candacia (Copepoda : Calanoida) with an annotated list of the species and a key for their identification.

__ 1963b. Deep water copepods from the western north Atlantic with notes of five species. Bulletin of Marine Science of the Gulf and Caribbean, 493-501. 13 (4).

1964. Two new species of Calanoid copepods from the Galapagos Island, with remarks on the identity of three other species. Crustaceana, 6 (4), 255-264.

Grice, G. D., and E. C. Jones 1960. Two new species of Candacia (Copepoda : Calanoida) from the central Pacific, with notes on two other species. Pacific Science, 14 (4) 280-291.

GurNey, R. 1927. Report on the Crustacea. Copepoda and Cladocera of the plankton. Trans. zool. Soc. London, Vol. 22, pt. 2, 139-172.

1927b. Report of the Crustacea. Copepoda (Littoral and Semi-parasitic). Cambridge Expedition to the Suez Canal, 1924. Trans. zool. Soc. London Vol. XXII, Pt. 4, 451-577. 1939. Bibliography of the larvae of Decapod Crustacea. London.

HARDY, A. S., and Gunther, E. R. 1935. The plankton of the South Georgia Whaling Ground and adjacent waters, 1926-1927. Discovery Report, Vol. 11, 1-456.

HEINRICH, A. K. 1957a. The distribution of Calanus tenuicornis Dana and Calanus lighti Bowman in the north Pacific. Doklady Akademii Nauk S. S. S. R. 116 (4), 691-693.

- 1957b. The vertical distribution of the plankton to the southeast from the Bonin Islands. Ibid., 117 (2), 321-324. (In Russian).

1958a. The vertical distribution of Copepods in the Kuroshio Current and the way they penetrate into the zone of mixing of subtropical and subarctic waters. Ibid, 118 (6), 1191-1192. (In Russian).

1958b. On the feeding of copepods in the tropical region. Ibid. 119 (5), 1028-1031.

HudA, T., and J. E. KING 1955. Vertical distribution of zooplankton in the central equatorial Pacific, July-August 1952. U. S. Fish and Wildlife Service, special scientific Report. Fisheries No. 144, 1-22.

HirotA, R. 1961. Zooplankton investigations in the Bingo-Nada region of the Setonaikai (Inland Sea of Japan). Jour. Sci. Hiroshima Univ. Series B. Div. I. Vol. 20, Art. 5, 83-144.

1962. Species composition and seasonal changes of copepod fauna in the vicinity of Mukaishima. Jour. Oceanogr. Soc. Japan. 18 (1), 35-40.

HoNJo, K. 1952. Distribution of Copepoda in the adjacent sea of the Izu Islands during winter and spring. Bulletin of the Tokai Regional Fisheries Research Laboratory, 4, 1-5. (In Japanese).

Honjo, K., Ohta, T., Kidachi, K., K. UMEdA and S. KudOH 1957. Distribution of Copepoda in the Kuroshio area, south of Honshu, May, 1955. Rec. Oceanogr. Works in Japan, Special Number, March, 1957, 120-129. 
Hulsemann, K., and G. D. Grice 1963. A new genus and species of bathypelagic calanoid copepod from the north Atlantic. Deep-Sea Research, 10, 729-733.

Jespersen, P. 1934. The Godthaab Expedition 1928. Copepoda. Medd. on Grönland 79, no. 10, 1-116.

1939a. Investigations on the Copepod Fauna in East Greeland waters. Medd. on Grönland 119, no. 9, 1-106.

1939b. The zoology of East Greelnand. Copepods. Ibid., 121, no. 3, 1-66.

1940a. Non-parasitic Copepoda. The zoology of Iceland. vol. III, Pt. 33, 1-116.

$1940 \mathrm{~b}$. Investigations on the quantity and distributions of zooplankton in Iceland

waters. Medd. Komm. Danmarks Fisk. Hav., Ser. Plankton, Bd. III, 1-78.

Johnson, M. W. 1932. Seasonal distribution of plankton at Friday Harbor, Washington. University of Washington Publications in Oceanography, Vol. 1, No. 1, 5-33.

1934a. The life history of copepod Tortanus discaudatus (Thompson and A. Scott 7). The Biological Bulletin, Vol. LXVII, No. 1, 5-33.

1934b. The developmental stages of the copepod Epilabidocera anphitites McMurrich.

Biological Bulletin, Vol. LXVV, No. 1, 466-483.

1935. The deveopmental stages of Labidocera. Ibid. Vol. LXVIII, No. 3, 347-421.

1937a. The developmental stages of the copepod Eucalanus elongatus Dana, var.

bungii Giesbrecht. Ibid. LVI, Vol. 1, 79-98.

1937b. Notes on the final matamorphsis of the male Aegisthus mucronatus Giesbrecht, and its bearing on the status of some uncertain species. Trans. American Microscopic Soc. Vol. LVI, No. 4, 505-509.

- 1938. Concerning the copepod Eucalanus elongatus Dana and its varieties in the northeast Pacific. Bull. Scripps Inst. Oceanogr, Univ. California Technical series, Vol. 4, No. 6., $165-180$.

- 1942. Concerning the hitherto unknown males of the copepods Microsetella rosea (Dana), Vettoria granulosa (Giesbrecht), and Corissa parva Farran. Trans. American Microscopic. Soc. Vol. LXI, No. 4, 430-437.

1949. Zooplankton as an index of water exchange between Bikini lagoon and the

open sea. Trans. American Geophysical Union Vol. 30, No. 2, 238-244.

1956. The plankton of the Beaufort and Chukchi sea areas of the arctic and its relation to the hydrography. Arctic Institute of North America Technical paper No. 1, 1-32.

- 1958. Bathycalanus sverdrupi n. sp., a copepod crustacean from great depths in the Pacific Ocean. Proc. Califoania Academy of Science, fourth series, vol. XXIX, No. 6, 257-265.

1963. Zooplankton collections from the high poarl basin
the copepoda. Limnology and Oceanography Vo. 8 No. 1, 89-102.

KITOU, M. 1958. Distribution of plankton copepods at the Ocean Weather Station "X" May 1950 to April 1951. Oceanogr. Magazine Vol. 10, No. 2, 193-199.

LEAviTT, B. B. 1935. A quantitative study of the vertical distribution of the larger zooplankton in the deep water. Biol. Bull. 69 (1), 115-130.

- 1938. The quantitative vertical distribution of macrozooplankton in the Atlantic Ocean basin. Biol. Bull. 74 (3), 376-394.

LÉGARÉ, J. E. H. 1957. The qualitative distribution of plankton in the Strait of Georgia in relation to certain oceanographic factors. Jour. Fish. Board of Canada 14 (4), 521-552.

MAÉDA, R. 1956. Plankton copepods in the Tsugaru Strait, northern Japan, as investigated by underway samplings. Bull. Fac. Fish., Hokkaido Univ. 7 (3), 225-232. (In Japanese.)

MARUkAWA, H. 1921. Plankton list and some new species of Copepoda from the northern waters of Japan. Bulletin Institute of Oceanography No. 384.

MARUMO, R., M. KrTou and O. AsAokA. 1960. Plankton copepod in the Northwestern Pacific Ocean in summer of 1958 . Oceanogr. Magazine Vol. 12 (1), 17-44. 
MORI, T. 1930. An annotated list of the pelagic Copepoda from the S.W. part of the Japan Sea with descriptions of two new species. Zoological Magazine 41 (487), 199-209. (In Japanese.) 1932. The pelagic copepods from southern Japan. Zoological Magazine, 44 (523), 1937. The pelagic Copepoda from neighbouring waters of Japan. Tokyo, 1-150.

1942. Systematic studies of the plankton organisms occurring in Iwayama Bay,

Palao. IV. Copepoda from the Bay and adjacent waters Palao Tropical Station Studies, 2 (3), 549-580.

Motoda, S. and M. ANRAKu. 1951. An observation on the vertical distribution of plankton at Ishikari Bay, Hokkaido. Jour. Oceanogr. Soc. Japan 6 (4), 194-201. (In Japanese.)

1952a. Observations on the plankton of Funka Bay, Hokkaido. I. Vertical distribution of plankton at the mouth of the bay in August 1950. Bulletin of the Hokkaido Regional Fisheries Laboratory, No. 5, 17-20. (In Japanese.)

1952b. Plankton investigations (spring and summer, 1951). Report of the Deep

Sea Fisheries of the northern Japan Sea, No. 3, 71-76. (In Japanese.)

- 1954. Daily change of vertical distribution of plankton animals near western

entrance to the Tsugaru Strait, northern Japan. Bulletin of the Faculty of Fisheries, Hokkaido University, 5 (1), 15-19.

- 1955. Marine plankton copepods from the Hachijo Island, Idzu Islands, Japan, with special reference to their vertical distribution. Record of Oceanographic Works in Japan 2 (1), 210-214.

MotodA, S., A. InzukA and M. ANRAku. 1950. Plankton distribution to the northwest of Hokkaido in summer 1949. Report of the deep sea fisheries of the northern Japan Sea, No. 1, 78-109. (In Japanese.)

NAKAI, Z. 1952. On the quantitative distribution of plankton reproduced in the northern Pacific.

Tokai Regional Fishereies Laboratory, special publication No. 2, 1-6.

Nemoto, T. 1963. Some aspects of the distribution of Calanus cristatus and C. plumchrus in the Bering and its neighbouring waters, with reference to the feeding of ballen whales. The scientific reports of the Whales Research Institute No. 17, 157-170.

Nicholls, A. G. 1944. Littoral Copepoda from south Australia. II. Calanoida, Cyclopoida, Notodelphyoida, Monstrilloida and Caligoida. Rec. South Australian Mus., Vol. 8 (1), 1-62. 1945. A new calanoid Copepoda from Australia. Ann. Mag. Nat. Hist. Ser. 11, Vol. 12, 501-514.

ODATE, K. 1962. On the properties of zooplankton in the northeastern sea region along the Pacific coast of Japan. Bulletin of the Tohoku Regional Fisheries Research Laboratory No. 21, 93-103.

Pavia, I. 1963. Contribuiçao para o estudo dos copépodes calaniudes de arquipélago de Cabo Verde. Traballios de dentro de biologia piscatoria No. 41, 1-82.

Pesta, O. 19 . Eine neue Pontella-spezies (Copepoda) aus dem südchinesischen Meer. Zool. Anzeiger, $102(3 / 4)$, 92-95.

Rose, M. 1929. Copépodes pélagiques particulierment de surface provenant des Campagnes Scientifiques du Prince Albert ler de Monaco. Résult. Camp. Sci. Monaco, Vol. 78, 1-126.

RUSSELL, F.S. 1934. The vertical distribution of marine macroplankton XII. Some observations on the vertical distribution of Calanus finmarchicus is relation to light intensity. Jour. Mar., Biol. Assoc., vol. XIX, No. 2, 569-584.

$\mathrm{XCV}, 5-30$.

1935. A review of some aspects of zoolplankton research. Rapp. Proc.-Verb., vol.

1936. Submarine illumination in relation to animal life. Ibid. CI, pt. 2.

SARS, G. O. 1903. Copepoda Calanoida. An account of the crustacea of Norway, vol. IV, $171 \mathrm{pp}$. Bergen.

1905. Liste préliminaire des calanoides recuilles pendant des campagnes de S.A.S. le Prince Albert de Monaco, avec diagnoses des genres et des espèces nouvelles. Ire partie. Bull. du Musée Oceanographique de Monaco, No. 26, 22 pp. 
SARS, G. O. 1907. Notes supplementaires sur les Calanoides de Princesse Alice (corrections et additions). Bull. l'institute Oceanogr. No. 101, $27 \mathrm{pp}$.

1911. An account of the Crustacea of Norway, vol. V. Copepoda Harpacticoida, 449 pp. Burgen.

1919. An Account of the Crustacea of Norway, vol. VII, Copepoda, Supplement, Pt. I and II. Calanoida, Harpacticoida (part), 1-24.

1920. Calanoides recueilles pendant les Campagnes de S.A.S. le Prince Albert de Monaco. Bull. l'institut Oceanographique, No. 377.

1925. Copépodes particulierement bathypelagique provenant des Campagnes Scienti-

fique du Prince Albert de Monaco. Resultats des Campagnes Scientifiques de Prince Albert de Monaco. Fascicule LXIX. Monaco, 408 pp.

SATO, CH. 1913. Pelagic copepods. Jour. Hokkaido Fish. Experimental station No. 1. (In Japanese.)

Schmaus, P. H., und K. Lehnhofer. 1927. Copepoda 4 : Rhincalanus Dana 1852 der Deutschen Tiefsee-Expedition, Systematik und Verbreitung der Gattung. Deutsche Tiefsee-Expedition 1898-1899. Bd. XXIII, Heft 8, 355-400.

ScotT, A. 1909. The Copepoda of the Siboga Expedition. Siboga Expeditie. Monograph XXIX, 323 pp. Leiden.

Scorr, T. 1894. Report on Entomostraca from the Gulf of Guinea. Trans. Linn. Soc. London, Zool. 2nd series, vol. VI, pt. 1, 1-161.

Senô, J., Y. Komaki and A. TAKedA. 1963. Reports on the "Umitaka-Maru" Expedition. Plackton collected by the "Umitaka-Maru" in the Antarctic and adjacent waters with special references to Copepoda. Jour. Tokyo Univ. Fisheries, vol. 49 (1), 53-62.

SEWELL, R. B. S. 1912. Notes on the surface-living Copepoda of the Bay of Bengal. Records of the Indian Meseum, vol. 7, 313-382.

1913. Notes on the biological work of the R.I.M.S.S. "Investigator" during survey season, 1910-11 and 1911-12. Jour. and Proc. Asiatic Soc. Bengal (new series), vol. 9 (8), $329-390$.

1914. Notes on the surface Copepoda of the Gulf of Mannar. Spolica Zeylanica, vol. IX, pt. $25,191-262$.

vol. $\mathrm{X}, 1-221$.

1932. The Copepoda of Indian Seas. Calanoida. Ibid. vol. X (continued), 223-407.

1933. Notes on a small collection of marine Copepoda from the Malay States.

Bulletin of the Raffles Museum, Singapore, Strait Settlements, No. 8, 25-31.

1940. Copepoda, Harpacticoida. The John Murray Expedition 1933-34, 1-382.

Scientific Reports, vol. VII, No. 2.

1947. The free swimming planktonic Copepoda. Systematic Account. John Murray

Expedition 1933-34. Scientific Report 8 (1), vol. 8, no. 1, 1-303.

1948. The free swimming planktonic Copepoda. Geographical distribution. John

Murray Expedition 1933-34. Scientific Reports, vol. VIII, No. 3, 21-592.

Shen, Chia-Jui, and Sye-O BAt. 1956. The marine Copepoda from the spawning ground of Pneumatophorus japonicus (Houttuyn) off Chefoo, China. Acta Zoologica Sinica 8 (2), 177234. (In Chinese.)

SMIRnov, S. 1929. Beiträge zur Copepodenfauna Ostasiens. Zool. Mus. Akademie Wissenschaften USSR. Sonderabdruck Zool. Anz, 81, Heft 11/12, 317-329.

1931. Zur Kenntnis der Copepodengattung Eurytemora GIESBR. Zool. Anz. Bd. 94, Heft 5/8, 194-201.

1936. Beschreibung einer neuen Acartia Art aus dem Japanischen Meer. Zool. Anz.

CXIV, Heft $3 / 4$.

STEUter, A. 1904. Copepoden der Valdivia-Expedition. Zool. Anz. Jahrg. XXVII. 
Steuer, A. 1910. Adriatische Planktoncopepoden. Sitzungsber. d. kaiserl. Akad. Wissenschaftten in Wien. Mathem-naturw. Klasse, Bd. CXIX, Abt. 1, 1-35.

1923. Bausteine zu einer Monographie der Copepodengattung Acartia. Arbeiten aus d. Zool. Institut d. Univ. Innsbruck. Bd. I, Heft 5, 1-56.

1926a. Revision der Copepodengattung Tortanus Giesbr. Bollettino della Societá Adriatica di Scienze Naturali-Trieste Vol. XXIX, 50-69.

1926b. Copepoda : Cephalophanes G.O. Sars 1907 der Deutschen Tiefsee Expedition, Systematik und Verbreitung der Gattung. Deutsche Tiefsee Expedition 1898-1899. Bd. XXII, Heft 4, 179-191.

1932. Copepoda 6: Pleuromamma GIESBR. 1898 der Deutschen Tiefsee-Expepition. Deutsche Tiefsee-Expedition 1898-1899. Bd. XXIII, Heft 1, 1-119.

1933. Zur planmässigen Erforschung der geographischen Verbreitung des Hali-

planktons, besonders der Copepoden. Zoogeographica, Bd. 1, 269-302.

1934. Two new species of copepods of the genus Acartia from Burma. Records of the Indian Museum. vol. XXXVI, 335-338, 1 pl.

TANAKa, O. 1935. Copepoda of Sagami Bay I. Family Eucalanidae. Proc. Sci. Fish. Assoc. Vol. 6 (4). (In Japanese.)

Japanese.)

1935b. Copepoda of Sagami Bay II. Family Candaciidae. Ibid. 6 (4). (In

1936. On some new species of Copepoda from Sagami Bay. Japanese Journal of

Zoology, Vol. VII, No. 1.

1937. Copepods from the deep water of Suruga Bay. Ibid. Vol. VII, No. 2.

1953. The pelagic copepods of the Izu region. Records of Oceanogr. Works in

Japan. Vol. 1, No. 1.

1956-1965. The pelagic copepods of the Izu region, Middle Japan, systematic

account I-XII. Publ. Seto Mar. Biol. Lab. vol. V, nos. 2, 3; vol. VI, nos. 1, 2, 3; vol. VIII, no. 1 ; vol. IX, no. 1 ; vol. X, no. 1 ; vol. XI, no. 1 ; vol. XII, no. 1 ; vol. XII, no. 5 .

1961. Pelagic Copepoda. Biological Results of the Japanese Antarctic Research

Expedition 10. Special Publ. from the Seto Mar. Biol. Lab.

Thompson, I. C., and A. ScotT. 1903. Report on Copepoda. Ceylon Pearl Oyster Fisheries, 1903. Supplementary Report, No. VII, 227-307.

TSuRutA, A. 1962. The plankton distribution in the northeast water of the Bering Sea during the summer in 1961. Jour. Shimonoseki College of Fisheries vol. 11 (3), 577-586.

1963. Distribution of plankton and its characteristics in the oceanic fishing grounds, with reference to their relation to fishery. Ibid. vol. 12 (1), 1-204.

Tsuruta, A., T. SATow, K. HAYAMA and T. ChIBA. 1959. Oceanographical and planktological studies of Tuna-fishing ground in the eastern part of the Indian Ocean. Ibid. 7 (1), 1-17.

UDA, M. 1935. Hydrographical researches on the normal monthly conditions of Oyashio Kuroshio area. Jour. Omp. Fish. Experimental station, no. 3.

1937. Results of hydrographical investifations in Sagami Bay in connection with the "Buri" (Seriola quinqeradiata T. et S.) fishing. Ibid. no. 8.

Ummerkutty, A. N. P. 1960. Studies of Indian copepods 4. Description of the female and a description of the male of Pseudodiaptomus ardjuna Brehm (Copepoda, Calanoida) with notes on the distribution and and affinities of the species. Jour. Mar. Biol. Assoc. India, 2 (2), $179-185$.

Vervoort, W. 1946. Biological results of the Snellius Expedition-XV. The bathypelagic Copepoda Calanoida of the Snellius Expedition. I. Families Calanoida, Eucalanidae, Paracalnidae, and Pseudocalanidae. Temminckia 8, 1-181.

1949. Some new and rare Copepoda Calanoida from east Indian Seas. Zoologische Verhandlingen, no. 5, 1-53. 
Vervoort, W. 1950. On the identity of Onchocalanus nudipes C. B. Wilson, 1942. Procedings of the section of Sciendes, Koniklijke Nederlandse Akademie van Wetenschappen 53 (1), 83-92. 1951. Plaukton copepods from the Atlantic sector of the Antarctic. Verhandlingen der Koninklijke Nederlandese Akademie van Wetenschppen Afdeeling Natuurkunde, Sect. 2. Vol. 47, 1-156.

1957. Copepods from Antarctic and sub-antarctic plankton samples. B.A. N.Z. Antarctic Research Expedition 1929-1931. Reports, Series B. (Zoology and Botany), 1-160. 1962. Report on some Copepoda collected during the Melanesia Expedition of the Osaka Museum of Natural History. Publ. Seto Mar. Biol. Lab. Vol. X, No. 2, 393-470.

VIVES, P. 1963. Sur les copépodes neritiques (Calanoida) de la Méditerranée occidentale (Côtes de Castellon, Espagne). Rapports et Proc.-verbaux des réunions de la C.I.E.S.M.M., Vol. XVII (2), 547-554.

WADA, S. K. 1953. Note on the ecology of a plankton copepod, Labidocera pavo GIESBRECHT. Records of Oceanogr. Works in Japan. vol. 1 (new series), 100-102.

WhEELER, W. M. 1900 . The free-swimming copepods of the Woods Hole region. U.S. Fish commission Bulletin for 1899. 157-192.

WILson, C. B. 1932. The copepods of the Woods Hole region, Massachusetts. U.S. National Museum Bulletin, 158, $635 \mathrm{pp}$.

1938. Plankton copepods collected during Admiral R. E. Byrd's Expedition to the Antarctic, 1933 to 1935 . Internat. Rev. ges Hsdrob. und Hydrogr. 36. 356-361.

1950. Copepods gathered by the United States Fisheries Steamer "Albatross" from 1887 to 1909 , chiefly in the Pacific Ocean. Smithsonian Institution United States National Museum, Bulletin 100, vol. 14, pt. 4, 141-441.

WITH, C. 1915. Copepoda: I. Calanoida Amphascandria. The Danish Ingolf Expedition, Vol. III. Copenhagen. 1-260.

WOLFENDEN, R. N. 1906. Notes on the collection of copepods. Fauna and geography of the Maldive and Laccadive Archipelagoes, Vol. II, 984-1040.

1908. Copepoda, Crustacea VIII. National History, vol. IV, Zoology. 1-46.

1911. Die marinen Copepoden, II. Die pelagischen Copepoden der Westwind Drift und der südlichen Eismeers. Deutsche Süd-polar Expedition, vol. XII, Pt. 4, Berlin. 181-380.

Wüst, G. 1929. Schichtung und Tiefenzirkulation des Pazifischen Ozeans. Veröff. Inst. Meereskunde, N.F., Heft 20, 1-64.

1937. Bodentemperatur und Bodenstrom in der Pazifischen Tiefsee. Ibid. Heft. 35.

YAMADA, T. 1933a. On the distribution of the temperate plankton in the western part of the Korean Strait. Bulletin of the Japanese Society of Scientific Fisheries 1 (6), 281-286. (In Japanese.)

1933b. Report on the distribution of the plankton in the neighbouring seas of Tyosen in June 1932. Annual Report of the Hydrographic Observatory of the Fishery Experimental Station. Goverment General of Tyosen, No. 7. A pendix. (In Japanese.)

1957. Notes on twenty species of zooplankton from Ômura-Bay. The Bulletin of the Faculty of Fisheries, Nagasaki University, No. 5, 1-13. (In Japanese.) 